\title{
Advanced Medical Therapies in the Management of Non-Scarring Alopecia: Areata and Androgenic Alopecia
}

\author{
Antonio Martinez-Lopez ${ }^{1,2}$, Trinidad Montero-Vilchez ${ }^{1}$, Álvaro Sierra-Sánchez ${ }^{3,4}$ (1), \\ Alejandro Molina-Leyva ${ }^{1,2, *(\mathbb{D})}$ and Salvador Arias-Santiago ${ }^{1,2,3,4,5}$ \\ 1 Dermatology Unit, Virgen de las Nieves University Hospital, Av de Madrid, 15, 18012 Granada, Spain; \\ antoniomartinezlopez@aol.com (A.M.-L.); tmonterov@gmail.com (T.M.-V.); \\ salvadorarias@hotmail.es (S.A.-S.) \\ 2 TECe19-Clinical and Translational Dermatology Investigation Group, Ibs.Granada, 18012 Granada, Spain \\ 3 Cell Production and Tissue Engineering Unit, Virgen de las Nieves University Hospital, Andalusian Network \\ of Design and Translation of Advanced Therapies, 18012 Granada, Spain; alvarosisan@gmail.com \\ 4 Biosanitary Institute of Granada (ibs.GRANADA), 18012 Granada, Spain \\ 5 Dermatology Department, Granada School of Medicine, Granada University, 18016 Granada, Spain \\ * Correspondence: alejandromolinaleyva@gmail.com
}

Received: 27 September 2020; Accepted: 6 November 2020; Published: 9 November 2020

\begin{abstract}
Alopecia is a challenging condition for both physicians and patients. Several topical, intralesional, oral, and surgical treatments have been developed in recent decades, but some of those therapies only provide partial improvement. Advanced medical therapies are medical products based on genes, cells, and/or tissue engineering products that have properties in regenerating, repairing, or replacing human tissue. In recent years, numerous applications have been described for advanced medical therapies. With this background, those therapies may have a role in the treatment of various types of alopecia such as alopecia areata and androgenic alopecia. The aim of this review is to provide dermatologists an overview of the different advanced medical therapies that have been applied in the treatment of alopecia, by reviewing clinical and basic research studies as well as ongoing clinical trials.
\end{abstract}

Keywords: androgenic alopecia; alopecia areata; mesenchymal stem cells; advanced medical therapies; tissue engineering; gene therapy

\section{Introduction}

Alopecia is one of the most common consultation requests in dermatological daily practice [1]. This condition is usually associated with some psychological disturbances such as anxiety, depression, and distress [2]. In recent decades, many topical, intralesional, oral, or surgical treatments have been employed in order to delay and stop the hair loss as well as to restore the presence of hair in alopecic areas. However, some of the therapeutic drugs employed in some conditions such as minoxidil, finasteride, and dutasteride for androgenic alopecia (AHA) only provide partial and temporary involvement. Moreover, treatments for severe alopecia areata (AA) and many forms of scarring alopecia are usually ineffective and sometimes are associated with serious adverse effects $[3,4]$. With this background, some alternative therapeutic strategies are needed for this disease.

The use of genes, cells, and tissues as a new therapeutic resource is one of the characteristics of contemporary medicine. Advances in regenerative medicine has increased interest in applying stem cells to engineered tissue scaffolds to reconstitute damaged tissue and develop regenerative therapies for the skin [5,6]. This new therapeutic approach is based on gene therapy, cell therapy, tissue engineering, or the combination of any type of drug with medical devices (Figure 1). As defined by the European Commission, Advanced Therapy Medicinal Products (ATMPs) are new medical 
products based on genes (i.e., recombinant nucleic acids, gene therapy), cells (cell therapy), and/or tissue engineered products that contain or consist of engineered cells or tissues and are presented as having properties for, or are used in or administered to, human beings with a view of regenerating, repairing, or replacing human tissue [7,8]. According to the Annex I to Directive 2001/83/EC, a somatic cell therapy medicinal product means a biological medicinal product that presents two main characteristics:

(a) Contains or consists of cells or tissues that have been subject to substantial manipulation so that biological characteristics, physiological functions, or structural properties relevant for the intended clinical use have been altered, or of cells or tissues that are not intended to be used for the same essential functions in the recipient and the donor;

(b) Is presented as having properties for, or is used in or administered to, human beings with a view of treating, preventing, or diagnosing a disease through the pharmacological, immunological, or metabolic action of its cells or tissues.

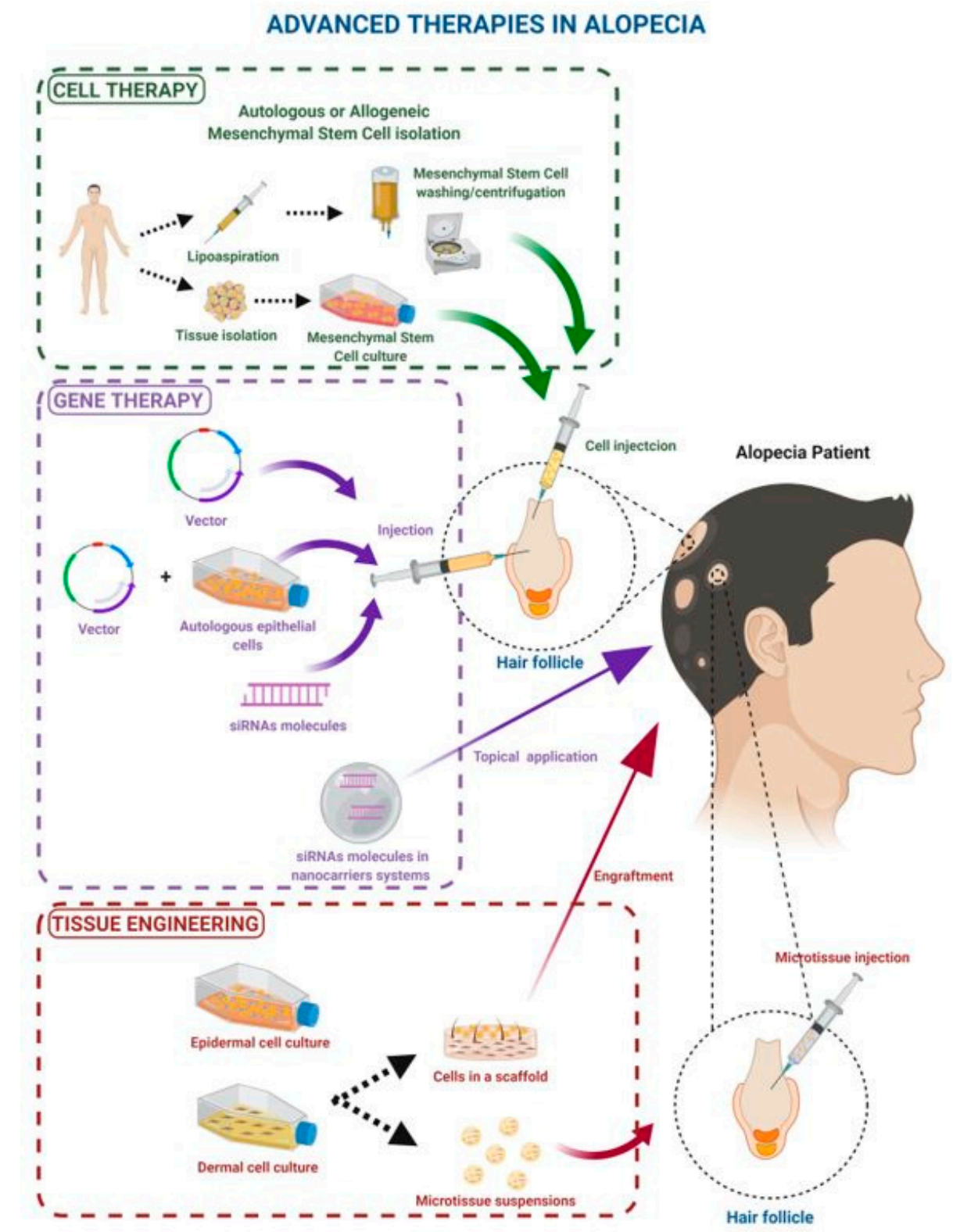

Figure 1. Advanced therapies and their use in alopecia: cell therapy, gene therapy, and tissue engineering therapy. Created with Biorender.com. 
Regarding point (a), the European regulation has established which manipulations should not be considered as substantial manipulations. In this way, cellular products obtained by centrifugation, irradiation, cell separation, concentration, or purification proceedings are not considered as ATMPs. Thus, common cellular treatments for some forms of alopecia like platelet-rich plasma could not be included into the ATMPs. Autologous fat injections for the treatment of alopecia are considered as an ATMP because they are used for a different purpose than originally intended, although their use is currently only approved in the setting of clinical trials. However, its illegal use has become extended in several cosmetic medicine centers, which entails serious legal implications [9].

ATMPs are complex products and risks may differ according to the type of product, nature/characteristics of the starting materials, and level of complexity of the manufacturing process. It is also acknowledged that the finished product may entail some degree of variability due to the use of biological materials and/or complex manipulation steps. In that way, ATMPs' quality plays a major role in their safety and efficacy profile. Compliance with Good Manufacturing Practice ("GMP") is an essential part of the pharmaceutical quality system and it is the responsibility of the ATMP manufacturer to ensure that appropriate measures are put in place to safeguard the quality of the product [10].

ATMPs are usually well tolerated, but some side effects have been described, especially with intravenous human mesenchymal stem cell (hMSC) therapy. MSC-based products express variable levels of a highly procoagulant tissue factor (TF/CD142) that could lead to venous thrombosis and thromboembolism. Thirabanjasak et al. reported a lupus nephritis patient who had angio-myeloproliferative lesions after direct injection of stem cells into the renal parenchyma [11]. Thus, it is advisable to weigh the risks and benefits of this treatment in patients with procoagulant diseases and thrombophilias. Low-grade fever has also been associated with hMSC infusion [12,13]. More data on the safety of stem cell application need to be collected.

ATMPs have numerous potential applications, especially in the field of regenerative medicine. With this background, the aim of this review is to outline the different forms of ATMPs and their application in the treatment of non-scarring alopecia forms such as alopecia areata and androgenic alopecia, by reviewing clinical and basic research studies as well as ongoing clinical trials.

\section{Mesenchymal Stem Cell Therapy}

HMSC-based therapies have been used in regenerative medicine in several medical areas such as orthopedics, neurology, cardiology, and dermatology. HMSCs originate from the mesoderm and share their origins with the skin. When these cells are implanted in a damaged tissue, they are likely to react better to paracrine factors; therefore, hMSCs are an ideal strategy for repairing and regenerating skin abnormalities (Figure 2) [5,13-15].

When these cells are administered to an area affected by different diseases, hMSCs can be differentiated into injured tissue components. In addition, these cells have shown an important immunomodulatory activity and are able to secrete various cytokines and growth factors such as Il-6, Il-7, Il-8, vascular endothelial growth factor (VEGF), basic fibroblast growth factor (bFGF), and epidermal growth factor (EGF) that promote tissue regeneration [16-19]. Although the main reserve of hMSCs is found in the bone marrow, adipose tissue has been identified as a source of these cells, displaying similar properties to those extracted from the bone marrow [20-22].

HMSCs have been used in several medical and surgical disciplines in order to explore new therapeutic possibilities for diseases which current treatment modalities do not offer satisfactory results. For example, in the orthopedic field, hMSC have been successfully used for osteonecrosis, osteoarthritis, and to promote fracture healing [23-26]. In dermatology, the main use of hMSCs has been focused on the treatment of wounds and skin ulcers. In that way, preclinical studies have shown that the application of hMSCs accelerates the re-epithelialization of skin wounds. This is due to the promoting action of dermal fibroblast proliferation by direct cellular contact and by transforming 
growth factor beta (TGF $\beta$ ) and bFGF secretion. In addition, its ability to differentiate into adipocytes provides a supportive architecture for dermal regeneration and re-epithelialization [27-31].

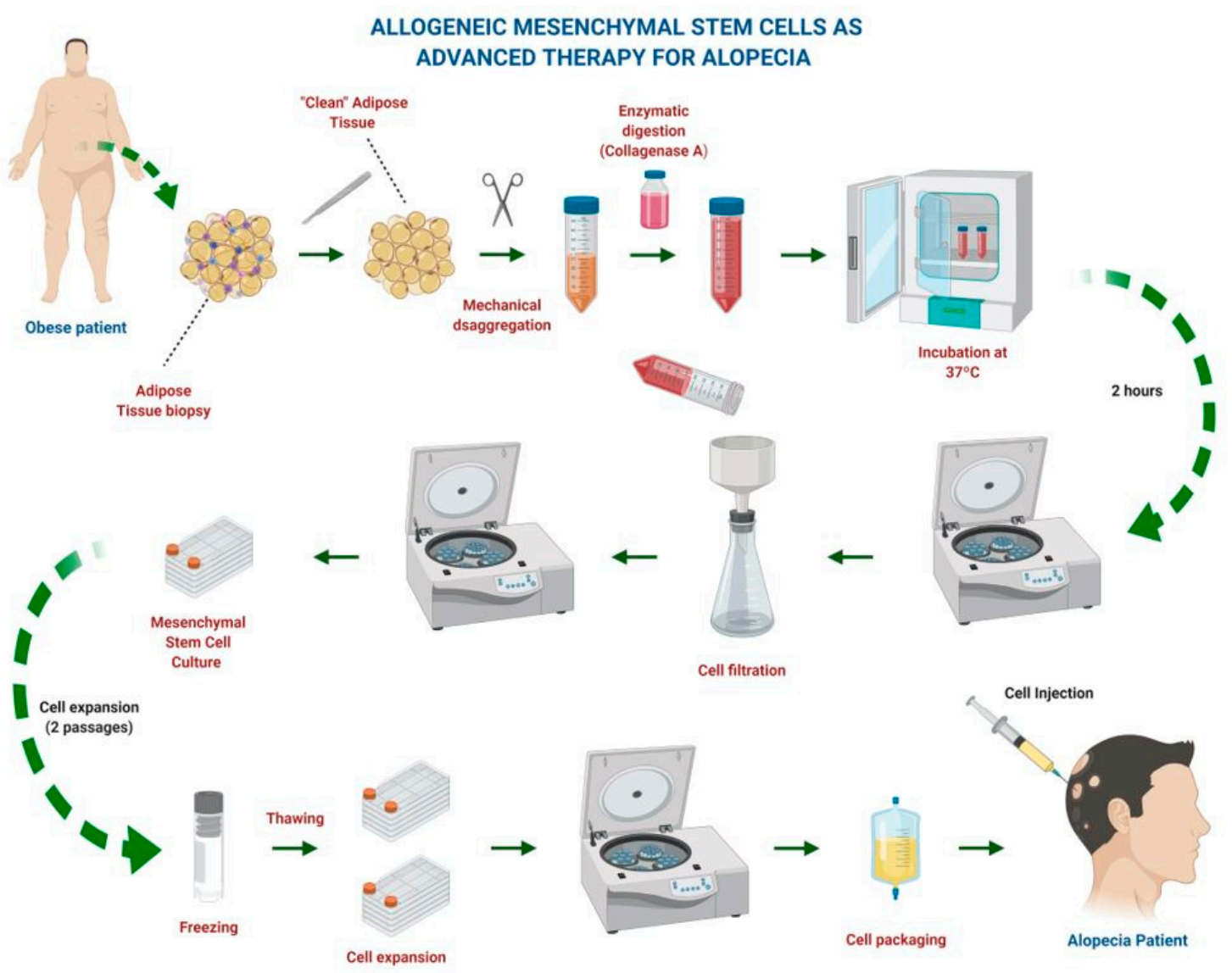

Figure 2. Procurement and production of mesenchymal stem cells. Created with Biorender.com.

The hair follicle (HF) is a regenerating system, which physiologically undergoes cycles of growth (anagen), regression (catagen), and rest (telogen). HF has a niche for mature stem cells in the attachment region of arrector pili muscles, which contain epithelial and melanocyte stem cells. Another type of stem cells within the hair follicle is dermal papilla cells, probably originating from dermal condensation, which is the initial stage of hair follicle development [32,33]. During adult HF cycling, the signal between epithelial keratinocytes and underlying specialized hair follicle and dermal papilla mesenchymal cells induces stem cell proliferation and initiates the cascade of cell differentiation into the hair follicle cell lineages [34]. These cells also take part in the regeneration of the sebaceous glands.

Hair loss is determined by several factors such as hereditary conditions, hormonal disorders, autoimmunity diseases, nutritional deficiency, bacterial and fungal overgrowth, psychological factors, environmental elements, and aging. Some of these harming factors influence the hair cycle and reduce stem cell activity and HF recovery capacity [33]. Immunologic disturbances use HF as one of their main targets. When the HF immune privilege is collapsed, CD4 and CD8 T cells and natural killer (NK) cells accumulate around the autoantigens of the hair bulb and contribute to the development of AA $[35,36]$. Multiple models have shown the association between the development of several types of alopecia with the disruption of certain cytokines and proteins. Th1 cytokines and chemokines, such as interferon-gamma (IFN- $\gamma$ ), CXCL9, and CXCL10, are predominantly detected in AA lesions and might induce the collapse of the hair follicle immune privilege [36]. CK15 immunoreactivity, which has been described as a marker of telogen, is decreased in people with active AA, whereas it is present in AHA. Hair follicles in the frontal parts of the scalp exhibit a deficit of CD34 in AHA, and its expression is preserved in hair follicles of the occipital region. Interfollicular injection of autologous CD34+ 
cell-containing PRP preparation has shown a positive therapeutic effect in AHA patients [37-39]. Moreover, CD200, another marker of matrix cells, is poorly expressed in patchy alopecia, which may be a sign of the disappearance of the immune privilege and can contribute to pathogenesis $[40,41]$. The Wnt pathway and Wnt/beta-catenin signaling are known to increase mammalian hair growth. In that way, Leirós et al. demonstrated that androgens deregulated dermal papilla cell-secreted factors involved in normal HF stem cell differentiation via the inhibition of the Wnt pathway [42].

Some preclinical studies have shown promising results by employing hMSCs in the treatment of AA and AHA (Table 1). Byun et al. developed a pilot study in order to demonstrate the immunomodulatory effect of MSC in AA. The investigators employed intravenous MSC in AA-induced C3H/HeJ mice on days 1 and 7, and after 15 weeks of follow-up, 23\% of mice in the MSC-treated group showed AA incidence, whereas extensive hair loss was observed in $91 \%$ mice in the control group. Serum samples also showed decreased IFN $\gamma$, CXCL9, and CXCL10 concentrations in the treated group. Moreover, histological analysis demonstrated less inflammatory cellular infiltration around the dermal papilla [35]. Later, Kim et al. launched another in vitro study with the aim of assessing the effect of hMSCs on the viability and proliferation of human dermal papilla cells (hDPC) via the activation of the JAK/STAT and Wnt/beta-catenin signaling pathways in an AA-model. The investigators employed bone marrow-derived hMSCs that were co-cultured with $\mathrm{hDPC}$, showing a $120 \%$ increased hDPC proliferation compared to hDPC cultured alone. In addition, hMSC treatment augmented beta-catenin levels and induced much higher phosphorylation of STAT1 and STAT3, proteins that are associated with a prolonged anagen phase. Finally, the investigators observed an immunomodulatory effect in the treatment with hMSC by restoring a HF privilege that induced re-entry signaling from the telogen to anagen phase [43]. Recently, Bak et al. conducted a mice-based study in order to evaluate the effect of umbilical cord blood hMSCs on reacquisition of hDPC conduction ability to induce hair growth. After 6 weeks of hMSC injection, a complete hair regrowth was observed. Moreover, histological analysis revealed that hMSC promoted hair follicle re-entry in the early and middle anagen phase prematurely compared with the minoxidil group. In addition, hMSC treatment up-regulated beta-catenin and AKT pathways and enhanced growth factors production [44].

Table 1. Preclinical studies of MSCs as advanced cell therapy for non-scarring alopecia.

\begin{tabular}{|c|c|c|c|c|c|}
\hline MSC Source & Type of Study & Experimental Design & Results & Conclusions & Reference \\
\hline $\begin{array}{l}\text { Human bone } \\
\text { marrow } \\
\text { (hBM-MSCs) }\end{array}$ & $\begin{array}{l}\text { In vivo study } \\
\text { Alopecia } \\
\text { Areata induced } \\
\text { in } 24 \\
\mathrm{C} 3 \mathrm{H} / \mathrm{HeJ} \text { mice. }\end{array}$ & $\begin{array}{l}\text { Control group }(n=11) \\
\text { and MSC group }(n=13) \text {. } \\
\text { Intravenous injection of } \\
\text { two doses of MSCs at } \\
\text { days } 1 \text { and } 7 . \\
\text { Mice were analysed for } \\
15 \text { weeks. }\end{array}$ & $\begin{array}{c}\text { 1-MSC-treated mice showed } \\
\text { decreased IFNG } \\
\text { concentration as early as } \\
5 \text { weeks } \\
\text { post-transplantation. } \\
\text { 2-Mice treated with MSCs } \\
\text { showed less inflammatory } \\
\text { cell infiltration in the dermis } \\
\text { and the number of hair } \\
\text { follicles was not decreased } \\
\text { compared with the } \\
\text { control group. }\end{array}$ & $\begin{array}{l}\text { 1-After } 15 \text { weeks } \\
\text { post-transplantation; } \\
91 \% \text { of control mice } \\
\text { experimented hair loss } \\
\text { against } 23 \% \text { of } \\
\text { MSC-treated group. } \\
\text { 2-MSCs mediate } \\
\text { inhibition of IFNG and } \\
\text { CD3 and CD8 + } \\
\text { NKG2D+ T-cell } \\
\text { infiltration which } \\
\text { protects against the } \\
\text { collapse of the } \\
\text { hair follicle } \\
\text { immune privilege. }\end{array}$ & [35] \\
\hline
\end{tabular}


Table 1. Cont.

\begin{tabular}{|c|c|c|c|c|c|}
\hline MSC Source & Type of Study & Experimental Design & Results & Conclusions & Reference \\
\hline $\begin{array}{l}\text { Human bone } \\
\text { marrow } \\
\text { (hBM-MSCs) }\end{array}$ & $\begin{array}{l}\text { In vitro study } \\
\text { in Alopecia } \\
\text { Areata induced } \\
\text { environment. }\end{array}$ & $\begin{array}{l}\text { Co-culture of human } \\
\text { dermal papilla cells } \\
\text { (hDPCs) }\left(1 \times 10^{5} \text { cells }\right. \\
\text { per well) pre-treated } \\
\text { with interferon gamma } \\
\text { (IFN- } \gamma) \text { to reproduce } \\
\text { Alopecia Areata } \\
\text { environment with } \\
\text { hBM-MSCs } \\
\left(5 \times 10^{4} \text { cells }\right) \text {. }\end{array}$ & $\begin{array}{l}\text { 1-hDPCs proliferation were } \\
\text { increased up to } \sim 120 \% \\
\text { compared to control cultures. } \\
\text { 2-Levels of } \beta \text {-catenin protein } \\
\text { which were suppressed by } \\
\text { IFN- } \gamma \text { treatment were } \\
\text { shown to be reversed by } \\
\text { hBM-MSCs. } \\
\text { 3-hMSCs induced higher } \\
\text { phosphorylation of STAT1 } \\
\text { and STAT3. } \\
\text { 4-hMSCs increased mRNA } \\
\text { expression of TNF- } \alpha \text { and } \\
\text { IL-1 } \beta \\
\text { 5-Growth factor analysis } \\
\text { revealed that co-culture of } \\
\text { hBM-MSCs and hDPCs } \\
\text { enhanced expression of } \\
\text { IGF-2, TGF- } \alpha, \text { TGF- } \beta 3 \text { and } \\
\text { NT- } 4 \text { which could be } \\
\text { involved in driving } \\
\text { anagen reentry. }\end{array}$ & $\begin{array}{l}\text { 1-hHMSC co-culture } \\
\text { could reverse } \\
\text { suppressed hDPC } \\
\text { proliferation and may } \\
\text { prolong the anagen } \\
\text { phase through activation } \\
\text { of the } \beta \text {-catenin/Wnt and } \\
\text { JAK/STAT } \\
\text { signalling pathways. } \\
\text { 2-hBM-MSCs in } \\
\text { refractory AA patients } \\
\text { might restore hair } \\
\text { follicles (HFs) immune } \\
\text { privilege through } \\
\text { immunomodulatory } \\
\text { effects and induce } \\
\text { reentry signalling from } \\
\text { the telogen to } \\
\text { anagen phase }\end{array}$ & [43] \\
\hline $\begin{array}{c}\text { Human } \\
\text { umbilical } \\
\text { cord blood } \\
\text { (hUCB-MSCs) }\end{array}$ & $\begin{array}{l}\text { In vivo study } \\
\text { in C3H/HeJ } \\
\text { mice } \\
\text { (Telogen-anagen } \\
\text { transition } \\
\text { model was } \\
\text { induced by } \\
\text { depilating the } \\
\text { dorsal skin of } \\
\text { mice in the } \\
\text { telogen phase } \\
\text { of the } \\
\text { hair cycle). }\end{array}$ & $\begin{array}{c}\text { Four groups of study } \\
\text { (6 weeks): } \\
\text { Control group } \\
\text { Minoxidil-treated group } \\
\text { Saline intra-dermal } \\
\text { injection-treated group } \\
\text { hUCB-MSC intra-dermal } \\
\text { injection-treated group } \\
\text { (8 sites- } 1 \times 10^{5} \\
\text { cells/mice) }\end{array}$ & $\begin{array}{l}\text { 1-After } 6 \text { weeks } \\
\text { post-treatment, hair } \\
\text { regrowth was complete in } \\
\text { the hUCB-MSCs group. } \\
\text { 2-Minoxidil-treated group } \\
\text { presented incomplete } \\
\text { pigmentation and contained } \\
\text { hairs in the early stage of the } \\
\text { hair cycle, } \\
\text { 3-Control and } \\
\text { Saline-injected groups } \\
\text { retained large areas without } \\
\text { anagen induction. }\end{array}$ & $\begin{array}{l}\text { 1-hUCB-MSCs can } \\
\text { accelerate the initiation } \\
\text { of the hair follicle } \\
\text { telogen-anagen } \\
\text { transition, increase the } \\
\text { number of hairs in vivo, } \\
\text { and enhance expression } \\
\text { of proteins related to } \\
\text { hair induction in vitro. } \\
\text { 2-IGFBP-1 (assumed as } \\
\text { the main secretory factor } \\
\text { of hUCB-MSCs) restores } \\
\text { and promotes the } \\
\text { hair-induction ability of } \\
\text { hDPCs via an } \\
\text { IGF-1/IGFBP-1 } \\
\text { co-localization. }\end{array}$ & [44] \\
\hline
\end{tabular}

Few clinical studies with advanced hMSC therapies have been conducted for several forms of alopecia, probably because of ethical considerations and the high cost of launching these studies (Table 2). Firstly, a group of Egyptian authors published clinical data on the use of hMSCs in the treatment of AA and AHA. In 2011, this group conducted a pilot study in eight AA patients in order to evaluate the effect of cultured and enhanced follicular stem cells (FSC) in the treatment of this condition. The FSC were extracted from a $4 \mathrm{~mm}$ skin punch biopsy from the scalp and the FSC were injected once in the affected areas. At the end of the 6-month evaluation period, 5/8 patients $(62.5 \%)$ achieved an excellent response, graded as an improvement of $50 \%$ or more. Two patients developed a good response (10-50\% of improvement), whereas one patient showed poor response [45]. Later, Elmaadawy et al. developed a blinded randomized clinical trial where the purpose was to evaluate the safety and efficacy of the use of autologous bone marrow-derived mononuclear cells (including hMSCs) 
obtained without substantial manipulation compared to advanced FSC treatment for the management of resistant cases of AA and AHA. Patients were divided into four groups: groups 1 (10 resistant AA patients) and 3 (10 resistant AHA patients) received a single injection of mononuclear cells and groups 2 (10 AA patients) and 4 (10 AHA patients) received a single injection of FSC. After six months of clinical, dermoscopic, and histopathologic follow up, all the patients showed very good or excellent responses, especially in female patients, although $45 \%$ of AA patients suffered recurrence after one year of follow up. Moreover, no significant differences in dermoscopic or histopathologic analysis were found between the two studied treatments. Those data showed promising clinical results with advanced hMSC therapies for AA and AHA, but the frequent relapses after one injection revealed the need of multiple sessions, especially in AA patients [46]. In 2015, a Chinese group conducted a phase 1/phase 2, open-label clinical trial with human cord blood stem cells (CB-SC) in nine patients with established AA. All the patients received a single treatment of intravenous CB-SC combined with a Stem Cell Educator (Tianhe Stem Cell Biotechnologies ${ }^{\circledR}$, Jinan, China). In order to carry out this Stem Cell Education Therapy, the patient's blood was passed through a Blood Cell Separator MCS+ (Haemonetics ${ }^{\circledR}$, Braintree, MA, USA) for 6 to $7 \mathrm{~h}$ to isolate mononuclear cells in accordance with the manufacturer's recommended protocol. The collected mononuclear cells were transferred into the device for exposure to allogeneic CB-SCs, and other blood components were automatically returned to the patient. After 2 to $3 \mathrm{~h}$ in the device, CB-SC-treated mononuclear cells were returned to the patient's circulation. The authors stated that all the patients tolerated the treatment well with a lack of serious adverse effects. Hair regrowth was noted after 4 weeks in patients with patchy and total AA. Moreover, $3 / 4$ of the universal AA patients showed short vellus hairs on the scalp in week 12. After a two-year follow-up, two patients achieved complete hair regrowth, with no relapses. Only one patient with universal AA failed to show a response with this therapy [47].

Table 2. Clinical studies of MSCs as advanced cell therapy for non-scarring alopecia.

\begin{tabular}{|c|c|c|c|c|c|}
\hline $\begin{array}{c}\text { MSC } \\
\text { Source/Clinical } \\
\text { Trial Title }\end{array}$ & Experimental Design & Pre-Treatment Data & Clinical Results & Conclusions & Reference \\
\hline $\begin{array}{l}\text { Autologous hair } \\
\text { follicle stem cells } \\
\text { from the lower } \\
\text { bulge areas }\end{array}$ & $\begin{array}{c}\mathrm{N}=8 \text { patients with } \\
\text { Alopecia Areata (AA). } \\
\text { One millilitre (in a } \\
\text { density of } 10^{5} \text { cells/mL) } \\
\text { was injected } \\
\text { intradermally once per } \\
\text { centimetre square using } \\
\text { a 23-gauge needle. } \\
\text { Clinical improvement } \\
\text { was assessed by } \\
\text { calculating the } \\
\text { percentage of the } \\
\text { difference in the AA at } \\
\text { the end of } 3 \text { months and } \\
6 \text { months in relation to } \\
\text { the baseline extent. }\end{array}$ & $\begin{array}{c}\text { The extent of } \\
\text { affection ranged } \\
\text { from } 25 \text { to } 70 \% \\
\text { (mean: } 48 \pm 15 \% \text { ). } \\
\text { Patients age ranged } \\
\text { from } 6 \text { to } \\
17 \text { years. (mean: } \\
10.12 \pm 3.68 \text { years). } \\
\text { The duration of } \\
\text { disease ranged from } \\
1 \text { to } 4 \text { years (mean: } \\
2.31 \pm 0.96 \text { years) }\end{array}$ & $\begin{array}{l}\text { 1-Patients showed } \\
\text { variable degrees of } \\
\text { response, } 20-80 \% \text { (mean: } \\
45 \pm 22 \% \text { ) from baseline } \\
\text { at the end of the third } \\
\text { month and } 30-100 \% \\
\text { (mean: } 69 \pm 27 \% \text { ) from } \\
\text { baseline at the end of the } \\
\text { sixth month. } \\
\text { 2-After } 6 \text { months, } \\
\text { excellent response was } \\
\text { achieved in five patients } \\
\text { (62.5\%), good response } \\
\text { was achieved in two } \\
\text { patients ( } 25 \% \text { ), whereas } \\
\text { one patient (12.5\%) } \\
\text { showed poor response. } \\
\text { 3-There was a negative } \\
\text { correlation between the } \\
\text { age of the patients and } \\
\text { the grade of response } \\
\text { they achieved, that is, } \\
\text { the younger the patient, } \\
\text { the better the response. }\end{array}$ & $\begin{array}{l}\text { 1-Approximately } \\
60 \% \text { of the } \\
\text { patients (the } \\
\text { excellent } \\
\text { responders) } \\
\text { reported } \\
\text { improved } \\
\text { quality of life. }\end{array}$ & [45] \\
\hline
\end{tabular}


Table 2. Cont.

\begin{tabular}{|c|c|c|c|c|c|}
\hline $\begin{array}{c}\text { MSC } \\
\text { Source/Clinical } \\
\text { Trial Title }\end{array}$ & Experimental Design & Pre-Treatment Data & Clinical Results & Conclusions & Reference \\
\hline $\begin{array}{l}\text { Autologous bone } \\
\text { marrow derived } \\
\text { mononuclear } \\
\text { cells (including } \\
\text { stem cells) and } \\
\text { follicular stems } \\
\text { cells }\end{array}$ & $\begin{array}{c}\mathrm{N}=40 \text { patients: } \\
20 \text { patients with resistant } \\
\text { Alopecia Areata (AA) } \\
\text { and } 20 \text { patients } \\
\text { with Androgenetic } \\
\text { Alopecia (AGA). } \\
\text { Four groups of study: } \\
{ }^{*} \text { Group } 1 \text { (10 resistant } \\
\text { AA patients) } \\
\text { *Group } 3 \text { (10 AGA } \\
\text { patients) } \\
\text { *These received a single } \\
\text { session of intradermal } \\
\text { injections of autologous } \\
\text { bone marrow derived } \\
\text { mononuclear cells } \\
\text { (BMMCs). } \\
\text { **Group } 2 \text { (10 resistant } \\
\text { AA patients) } \\
\text { **Group } 4 \text { (10 AGA } \\
\text { patients) } \\
\text { **These received a single } \\
\text { session of intradermal } \\
\text { injections of autologous } \\
\text { follicular stem } \\
\text { cells (FSC). } \\
\text { One millilitre (in a } \\
\text { density of } 10^{5} \text { cells/mL) } \\
\text { was injected } \\
\text { intradermally once per } \\
\text { centimetre square using } \\
\text { a } 26 \text {-gauge needle. } \\
\text { Clinical improvement } \\
\text { was assessed at } 3 \text { and } \\
6 \text { months }\end{array}$ & $\begin{array}{l} \\
\text { The extent of } \\
\text { affection ranged } \\
\text { from; } \\
\text { Mean Group 1: } \\
44 \pm 20.65 \% \\
\text { Mean Group } 2: \\
46 \pm 18.97 \% \\
\text { Mean Group } \\
\text { 3: } 58 \pm 19.32 \% \\
\text { Mean Group } \\
4: 50 \pm 0 \% \\
\text { The ages of the } \\
\text { patients ranged from; } \\
\text { 10-50 years } \\
\text { (mean } 26 \pm 8 \text { years). } \\
\text { All patients were } \\
\text { resistant to } \\
\text { conventional } \\
\text { treatments. } \\
\text { The duration of } \\
\text { disease ranged from; } \\
\text { Mean Group 1: } \\
2 \pm 1 \text { years } \\
\text { Mean Group } 2: \\
1.5 \pm 0.7 \text { years } \\
\text { Mean Group } 3: \\
2 \pm 0.9 \text { years } \\
\text { Mean Group } 4: \\
1.9 \pm 0.8 \text { years }\end{array}$ & $\begin{array}{l}\text { 1-The mean percentage } \\
\text { of improvement in AA } \\
\text { patients was } 45 \pm 22 \% \\
\text { in AA subjects receiving } \\
\text { autologous BMMCs and } \\
58 \pm 34 \% \text { in AA subjects } \\
\text { receiving autologous } \\
\text { FSC with } \\
\text { non-statistically } \\
\text { significant difference. } \\
\text { 2-The mean percentage } \\
\text { of improvement in AGA } \\
\text { patients was } 52 \pm 28 \% \\
\text { in AGA subjects } \\
\text { receiving autologous } \\
\text { BMMCs and } 42 \pm 27 \% \text { in } \\
\text { AGA subjects receiving } \\
\text { autologous FSCs with } \\
\text { non-statistically } \\
\text { significant difference. } \\
3-45 \% \text { of AA } \\
\text { patients suffered } \\
\text { recurrence of disease } \\
\text { activity after one year of } \\
\text { follow up mostly due to } \\
\text { their stressful life events. }\end{array}$ & $\begin{array}{l}\text { 1-BMMCs and } \\
\text { FSCs gave } \\
\text { significant } \\
\text { improvement } \\
\text { in AGA and } \\
\text { AA with no } \\
\text { statistically } \\
\text { significant } \\
\text { difference } \\
\text { between both } \\
\text { methods. } \\
\text { 2-Autologous } \\
\text { BMMCs and } \\
\text { autologous FSC } \\
\text { seem to be a } \\
\text { safe, tolerable } \\
\text { and effective } \\
\text { treatment }\end{array}$ & [46] \\
\hline $\begin{array}{l}\text { Autologous } \\
\text { blood } \\
\text { mononuclear } \\
\text { cells “educated" } \\
\text { with allogeneic } \\
\text { umbilical cord } \\
\text { blood stem cells } \\
\text { Stem Cell } \\
\text { Educator } \\
\text { Therapy }\end{array}$ & $\begin{array}{l}\mathrm{N}=9 \text { patients:9 alopecia } \\
\text { areata patients (AA). } \\
\text { All of them received a } \\
\text { Stem Cell Educator } \\
\text { Therapy consisting in } \\
\text { autologous blood } \\
\text { mononuclear cells } \\
\text { isolated using a Blood } \\
\text { Cell Separator MCS+ } \\
\text { (6-7 h) and then, } \\
\text { transferred into the } \\
\text { Educator device for } \\
\text { exposure to allogeneic } \\
\text { cord blood stem cells } \\
\text { (CB-SCs) ex vivo } \\
\text { cultured and prepared } \\
\text { (2-3 h). } \\
\text { After this time, } \\
\text { CB-SC-treated } \\
\text { mononuclear cells were } \\
\text { returned to the patient's } \\
\text { circulation via a dorsal } \\
\text { vein in the hand } \\
\text { (16-gauge IV needle) } \\
\text { with physiological saline } \\
\text { (2 to } 3 \text { mL/min). } \\
\text { Follow-up visits were } \\
\text { scheduled } 4,12,24,40, \\
56,84, \text { and } 112 \text { weeks } \\
\text { after treatment for } \\
\text { clinical assessments and } \\
\text { laboratory tests. Skin } \\
\text { biopsies of scalps were } \\
\text { performed before the } \\
\text { treatment and at } 12 \\
\text { weeks post-treatment. }\end{array}$ & $\begin{array}{l}\text { The degree of } \\
\text { affection ranged } \\
\text { from patchy alopecia } \\
\text { areata (3), alopecia } \\
\text { totalis (2) to alopecia } \\
\text { universalis (4). } \\
\text { Mean alopecic } \\
\text { duration: } \\
5.1 \pm 6.1 \text { years. } \\
\text { The ages of the } \\
\text { patients ranged from; } \\
\text { 12-26 years } \\
\text { (mean } 20.1 \pm 4.6 \\
\text { years). }\end{array}$ & $\begin{array}{l}\text { 1-At } 4 \text { weeks } \\
\text { post-treatment with } \\
\text { Stem Cell Educator } \\
\text { therapy, there was hair } \\
\text { regrowth in subjects } \\
\text { with patchy AA and } \\
\text { alopecia totalis. } \\
\text { 2-Patients (3/4) with } \\
\text { alopecia universalis } \\
\text { exhibited regrowth of } \\
\text { eyebrows and eyelashes } \\
\text { at the 12-week follow-up. } \\
\text { 3-All these } \\
\text { improvements were } \\
\text { maintained throughout } \\
\text { the final follow-up at } 2 \\
\text { years. } \\
\text { 5-Only one participant } \\
\text { with alopecia universalis } \\
\text { failed to show a } \\
\text { response to the Stem Cell } \\
\text { Educator therapy, } \\
\text { possibly due to a } \\
\text { previous long-term } \\
\text { therapy with oral } \\
\text { prednisone }\end{array}$ & $\begin{array}{l}\text { 1-This phase } \\
\text { 1/phase } 2 \text { study } \\
\text { demonstrates } \\
\text { the safety and } \\
\text { feasibility of } \\
\text { Stem Cell } \\
\text { Educator } \\
\text { therapy in the } \\
\text { treatment of } \\
\text { AA subjects. } \\
\text { 2-Stem Cell } \\
\text { Educator } \\
\text { therapy can } \\
\text { control the } \\
\text { autoimmunity } \\
\text { and lead to hair } \\
\text { regrowth. }\end{array}$ & [47] \\
\hline
\end{tabular}


Table 2. Cont.

\begin{tabular}{|c|c|c|c|c|c|}
\hline $\begin{array}{c}\text { MSC } \\
\text { Source/Clinical } \\
\text { Trial Title }\end{array}$ & Experimental Design & Pre-Treatment Data & Clinical Results & Conclusions & Reference \\
\hline $\begin{array}{c}\text { Autologous } \\
\text { adipose cell } \\
\text { enriched with } \\
\text { stromal vascular } \\
\text { fraction (SVF) }\end{array}$ & $\begin{array}{c}\mathrm{N}=9 \text { patientswith } \\
\text { androgenic alopecia } \\
\text { (AHA). } \\
\text { The adipose cells were } \\
\text { injected into the scalp of } \\
\text { the patient in a } \\
\text { single dose. } \\
1 \mathrm{~mL} / \mathrm{cm}^{2} \text { scalp was } \\
\text { injected. The } \\
\text { composition was a } \\
\text { mixture of } \\
\text { adipose-enriched SVF } \\
\text { cells and Lactated Ringer. } \\
\text { Follow-up for hair count, } \\
\text { anagen percentage, } \\
\text { telogen percentage and } \\
\text { cumulative thickness at } \\
\text { weeks } 6,12 \text { and } 24 .\end{array}$ & $\begin{array}{l}\text { Degree of affection: } \\
\text { Hamilton } \\
\text { II-VI/Ludwig I-III } \\
\text { Average age: } 29 \\
\text { (range 19-54) } \\
\text { Average volume of } \\
\text { adipose cells injected: } \\
30 \mathrm{~mL}\end{array}$ & $\begin{array}{c}\text { 1-Hair count was } \\
\text { significantly augmented } \\
\text { after } 24 \text { weeks } \\
(28.4 \pm 17.3 ; p=0.010) . \\
\text { 2-Percentage of anagen } \\
\text { hair was increased but } \\
\text { did not reach a statistical } \\
\text { significance ( } p=0.094) . \\
\text { 3-Percentage of telogen } \\
\text { hair was decreased but } \\
\text { did not reach a statistical } \\
\text { significance ( } p=0.094) . \\
\text { 4-Cumulative thickness } \\
\text { was augmented but did } \\
\text { not reach a statistical } \\
\text { significance ( } p=0.133) .\end{array}$ & $\begin{array}{l}\text { 1-Enriched } \\
\text { adipose cells } \\
\text { injections may } \\
\text { be a promising } \\
\text { approach for } \\
\text { treating AHA } \\
\text { in both men } \\
\text { and women. }\end{array}$ & [48] \\
\hline $\begin{array}{c}\text { Autologous } \\
\text { adipose-derived } \\
\text { stromal vascular } \\
\text { cells (ADSVCs) }\end{array}$ & $\begin{array}{c}\mathrm{N}=20 \text { patients } \\
\text { with confirmed } \\
\text { diagnostic of hair loss. } \\
\text { The ADSVCs were } \\
\text { injected into the scalp of } \\
\text { the patient with a } \\
\text { 30-gauge needle. A total } \\
\text { of } 5 \text { mL was injected in } \\
25 \text { spots. } \\
4 \text { to } 4.7 \times 10^{6} \text { cells were } \\
\text { transplanted: in fact, } \\
0.2 \text { mL containing } \\
0.160-0.188 \times 10^{6} \text { cells } \\
\text { were injected per spot } \\
\text { (total = } 25 \text { spots, } 5 \text { mL) } \\
\text { Follow-up for hair } \\
\text { evaluation was based on } \\
\text { the hair cycles and was } \\
\text { performed } 1 \text { week, } \\
3 \text { months, and } 6 \text { months } \\
\text { after the procedure. }\end{array}$ & $\begin{array}{l}\text { All the selected } \\
\text { subjects showed } \\
\text { partial alopecia } \\
\text { grade } 1 \text { or } 2 \text { at } \\
\text { Ludwig Scale. } \\
\text { The ages of the } \\
\text { patients ranged from; } \\
20-63 \text { years(mean } \\
38.3 \pm 2.3 \text { years). } \\
55 \% \text { of the patients } \\
\text { showed medium } \\
\text { diameter hair and } \\
45 \% \text { showed fine hair. } \\
\text { Study subjects } \\
\text { showed abnormal } \\
\text { hair density (density } \\
<175 \text { hair/ cm }{ }^{2} \text { in } \\
100 \% \text { of the subjects) }\end{array}$ & $\begin{array}{c}\text { 1-Hair diameter } \\
\text { increased significantly, } \\
\text { especially } 6 \text { months after } \\
\text { the treatment }(80.8 \pm 2.4 \\
\mu \text { and } 62.8 \pm 1.7 \mu \text { vs. } \\
60.5 \pm 1.8 \mu \text { for } 6 \text { and } 3 \\
\text { months postoperatively } \\
\text { vs. preoperatively). } \\
\text { 2-Hair density was } \\
\text { significantly augmented } \\
\text { after treatment ( } 121.1 \pm \\
12.5 \text { and } 120.8 \pm 12.6 \text { vs. } \\
85.1 \pm 8.7 \text { for } 6 \text { and } 3 \\
\text { months postoperatively } \\
\text { vs. preoperatively). } \\
\text { 3-Results of the pull test } \\
\text { showed a significant } \\
\text { decrease in the number } \\
\text { of extracted hair }(0.80 \pm \\
0.17 \text { and } 0.90 \pm 0.20 \text { vs. } \\
4.35 \pm 0.33 \text { for } 6 \text { and } 3 \\
\text { months postoperatively } \\
\text { vs. preoperatively). } \\
4-2 \text { of the } 20 \text { patients } \\
\text { showed no significant } \\
\text { improvements. }\end{array}$ & $\begin{array}{l}\text { 1-ADSVC } \\
\text { injection } \\
\text { promotes good } \\
\text { stability of the } \\
\text { hair by } \\
\text { increasing the } \\
\text { hair density, the } \\
\text { hair diameter, } \\
\text { and decreasing } \\
\text { the pull test to } \\
\text { almost zero. }\end{array}$ & [49-52] \\
\hline
\end{tabular}

Regarding autologous fat injection obtained by lipoaspiration, a 9-patient case series was published in 2017. In this study, the investigators employed a scalp injection of adipose cells obtained by a liposuction surgical technique enriched with a stromal vascular fraction (SVF) in patients with AHA. After 24 weeks of follow up, an increase in the number of hairs $/ \mathrm{cm}^{2}$ measured by TrichoScan was noted [48]. Later, another group employed autologous adipose-derived stromal vascular cells (ADSVCs) in twenty patients with AA. In this paper, a significant increase in hair density and hair diameter was noted after a 6-month follow-up. Moreover, a significant decrease in the number of extracted hairs measured by a pull test was also found [49]. Finally, an anecdotical case report has shown the possible positive effect of autologous fat injections for scarring alopecia [50].

Recently, some authors have published their experience with Rigenera ${ }^{\circledR}$ technology in patients with AHA. After extracting three 3-mm scalp samples, the tissues were disaggregated by employing Rigeneracons ${ }^{\circledR}$ and, after that, the solution was rotated in the Rigenera machine allowing them to obtain the micrografts. This treatment was directly infiltrated into the scalp of the 100 included patients as a mesotherapy and, after a two-month follow-up, TrichoScan ${ }^{\circledR}$ revealed an increase in hair density and total hair count [51]. 
Some other clinical trials with advanced hMSC and cellular therapy have been carried out in the last decade. In the beginning of the 2010s, a multicentric North American phase 2 study was conducted in order to evaluate and compare the efficacy of injections of ex vivo cultured and enhanced occipital autologous dermal and epidermal cells vs. dermal cells alone-two non-HMSC cellular therapies-in patients with hair loss. However, no further results of this study have been published yet [52]. Currently, a Lebanese group is recruiting patients for an open-label non-randomized clinical trial aiming to assess the effect of adipose-derived cultured hMSCs obtained by lipoaspiration and to compare their efficacy with non-cultured hMSCs. This group has experience with the employment of adipose-derived hMSCs in patients with AA, a therapy which has shown good clinical results $[49,53]$. Moreover, some other clinical trials are also evaluating the effectiveness and safety of autologous ex vivo expanded dermal and epidermal cultured cells in subjects with AA and AHA. Those trials are still in a pre-therapeutic phase and no results are available [54-56].

\section{Gene Therapy in Alopecia}

Gene therapy is a new approach to discover and treat many diseases, including alopecia. Gene-based therapeutics are broadly defined as using a vector to introduce nucleic acids into cells with the aim of altering gene expression to prevent, halt, or reverse a pathological process [57]. The skin was one of the first targets for experimental gene transfer, as it is a superficial organ, easy to manipulate and observe [58]. In gene therapy techniques, genetic material is usually transferred using modified vectors directly into a subject's epidermal tissue (in vivo) or indirectly (ex vivo). When ex vivo techniques are used, cells are removed from the host, they are genetically manipulated, and then, reconstituted into the subject's skin [59].

Gene therapy through RNA interference has been considered one of the most recent and revolutionary approaches used in individualized therapy. In fact, gene silencing and knockdown by topical siRNA has rapidly developed in recent years and its application in gene therapy has become an attractive alternative for drug development [60]. RNA interference by small interfering RNA (siRNA) is a technique to suppress the expression of certain genes with a high specificity [61].

The use of topical siRNA is limited because of its low permeability through the epidermis, its high molecular weight, its negative charge, and its susceptibility to degradation by endogenous enzymes [62-64]. For this reason, efforts in topical siRNA delivery are being focused on chemical methods to prepared carrier molecules able to mask siRNA-negative charges, compress the siRNA molecule to make it smaller, and protect siRNA from degradation as well as the use of physical methods [65].

Regarding chemical methods, currently, carriers of siRNA can be classified into two categories: viral and non-viral. Non-viral vectors are preferred because they have less toxicity, less immunogenicity, and easier preparation, but they present a low-efficiency transient gene expression [66,67]. Non-viral carriers typically involve complexing of siRNA with different compounds such as polymers, cationic lipids, cell penetration peptides nanocarriers, or others. Using nanocarriers has been shown to efficiently encapsulate siRNA, providing protection against degradation and greatly improving the efficiency of delivery [68].

Besides the advancement in nanocarriers systems, the release of the siRNA into the cellular cytoplasm (site of biological activity) remains low range [69]. As an alternative, different physical methods have been proposed to facilitate molecular permeability through non-endosomal cellular penetration, transferring the siRNA directly to the cellular cytosol facilitating the endosomal escape of the siRNA [70]. Iontophoresis, microneedle array devices, and ultrasound technique are the physical methods most employed for improving efficient delivery of either naked or loaded siRNA into the skin and promotion of gene silencing [60].

Nakumura et al. reported the effective controlled delivery of small interfering RNA using biodegradable cationized gelatin microspheres in an animal model of alopecia areata and demonstrated the specific inhibition of target gene expression, resulting in a restoration of hair shaft elongation 
(Table 3). They firstly proved the dominant role of Th1 cells in the alopecic areas, as the infiltrating CD4 $\mathrm{T}$ lymphocytes around the hair follicles of patients with alopecia areata were primarily CCR5-positive with few CCR4-positive cells. After that, they tried to reveal the effect of cytokine therapy in $\mathrm{C} 3 \mathrm{H} / \mathrm{HeJ}$ mice, a mouse model of alopecia areata, by applying recombinant Il-4 and neutralizing anti-interferon antibody local injections. They found that both effectively treated alopecia in in $\mathrm{C} 3 \mathrm{H} / \mathrm{HeJ}$ mice and demonstrated that intralesional injection of Il-4 suppressed CD8 T cell infiltrates around the hair follicles and repressed enhanced interferon mRNA expression in the affected alopecic skin. The siRNA used in this work was targeted to T-box21 (Tbox transcription factor), in order to inhibit the transcription factor responsible for the cytokine Th1 production. Therefore, Th1 T-box21 siRNAs conjugated to cationized gelatin showed mitigating effects on alopecia in $\mathrm{C} 3 \mathrm{H} / \mathrm{HeJ}$ mice, resulting in the restoration of hair shaft elongation. In that way, they demonstrated the use of gelatin-small interfering RNA conjugates as an efficient and safe tool for alopecia areata [71].

Table 3. Preclinical studies of Gene Therapy for non-scarring alopecia.

\begin{tabular}{|c|c|c|c|c|c|}
\hline $\begin{array}{c}\text { Type of Gene } \\
\text { Therapy }\end{array}$ & Type of Study & Experimental Design & Results & Conclusions & Reference \\
\hline $\begin{array}{l}\text { Intralesional } \\
\text { injections of } \\
\text { oligonucleotides } \\
\text { and siRNAs }\end{array}$ & $\begin{array}{l}\text { In vivo study } \\
\text { Older female } \\
\mathrm{C} 3 \mathrm{H} / \mathrm{HeJ} \text { mice } \\
\text { having an } \\
\text { alopecic region } \\
\text { on the back in } \\
\text { the waxing } \\
\text { phase. }\end{array}$ & $\begin{array}{l}\mathrm{N}=78 \mathrm{C} 3 \mathrm{H} / \mathrm{HeJ} \text { mice } \\
\text { with alopecic lesions } \\
\text { (develop hair loss } \\
\text { spontaneously): } \\
\text { Group 1: Treatment with } \\
\text { Il4 injections }(n=10) \\
\text { Group 2: Treatment with } \\
\text { 0.9\% sodium chloride } \\
\text { injections }(n=10) \\
\text { Group 3: Treatment with } \\
\text { Il4 and Ifng injections } \\
\text { ( } n=10) \\
\text { Group 4: Treatment with } \\
\text { anti-Ifng antibody } \\
\text { injections }(n=6) \\
\text { Group 5: Treatment with } \\
\text { rat IgG injections }(n=6) \\
\text { Group 6: Treatment with } \\
\text { antisense Tbx21 } \\
\text { oligonucleotide } \\
\text { injections }(n=6) \\
\text { Group 7: Treatment with } \\
\text { non-sense } \\
\text { oligonucleotide } \\
\text { injections }(n=6) \\
\text { Group 8: Treatment with } \\
\text { cationized } \\
\text { gelatin-conjugated } \\
\text { Tbx21 siRNA } \\
\text { injections }(n=8) \\
\text { Group 9: Treatment with } \\
\text { naked Tbx21 siRNA } \\
\text { injections }(n=8) \\
\text { Group 10: Treatment } \\
\text { with cationized } \\
\text { gelatin-conjugated } \\
\text { non-sense siRNA } \\
\text { injections }(n=8) \\
\text { and }\end{array}$ & $\begin{array}{l}\text { 1-Intralesional injections of } \\
\text { recombinant Il4 (0.1 } \mu \text { g) } \\
\text { (Group 1) every day for } 3 \\
\text { weeks significantly restored } \\
\text { hair shaft elongations when } \\
\text { compared with the sodium } \\
\text { chloride injections (Group 2). } \\
\text { There was no recurrence of } \\
\text { alopecia from these mice } \\
\text { during a 2-month. } \\
\text { 2-Il4 effect was suppressed by } \\
\text { the simultaneous injection of } \\
\text { 0.01 } \mu \text { g of recombinant } \\
\text { Ifng (Group 3). } \\
\text { 3-Anti-Ifng antibody } \\
\text { injections (Group 4) improved } \\
\text { the hair growth index more } \\
\text { efficiently than the control rat } \\
\text { IgG (Group 5). There was no } \\
\text { disappearance of hair shafts } \\
\text { from these mice during a } \\
\text { 2-month observation period } \\
\text { after the cessation of } \\
\text { antibody application. } \\
\text { 4-Antisense Tbx21 } \\
\text { oligonucleotide (Group 6) was } \\
\text { significantly more effective for } \\
\text { alopecia than non-sense } \\
\text { oligonucleotide (Group 7). } \\
\text { 5-Cationized } \\
\text { gelatin-conjugated Tbx } 21 \\
\text { siRNA injections (Group } 8 \text { ) } \\
\text { were more effective than } \\
\text { naked Tbx21 siRNA injections } \\
\text { (Group 9) or non-sense siRNA } \\
\text { conjugated with cationized } \\
\text { gelatin (Group 10). There was } \\
\text { no recurrence of alopecia in } \\
\text { the mice during a 2-month } \\
\text { observation period after the } \\
\text { cessation of Tbx21 } \\
\text { siRNA application. }\end{array}$ & $\begin{array}{l}\text { 1-Intralesional } \\
\text { injections of Il4 } \\
\text { suppressed an } \\
\text { enhanced expression } \\
\text { of Ifng in } \\
\text { alopecic skin. } \\
\text { 2-Intralesional } \\
\text { injections of Tbx21 } \\
\text { antisense } \\
\text { oligonucleotide } \\
\text { restored the hair } \\
\text { shaft elongation. } \\
\text { 3-Efficient and safety } \\
\text { delivery of Tbx21 } \\
\text { siRNA to alopecic } \\
\text { skin using a } \\
\text { biodegradable } \\
\text { cationized gelatin } \\
\text { demonstrated } \\
\text { specific inhibition of } \\
\text { target gene } \\
\text { expression (Ifng) } \\
\text { resulting in a } \\
\text { restoration of hair } \\
\text { shaft elongation. }\end{array}$ & [71] \\
\hline
\end{tabular}

Four microRNAs_-miR-221, miR-125b, miR-106a, and miR-410—were proved to be upregulated in balding papilla cells. In that way, they could participate in the pathogenesis of male pattern baldness. Therefore, it was suggested these microRNAs were possible candidates for a gene therapy regarding the strong therapeutic potential of microRNAs and the easy accessibility of hair follicles for gene therapy [72]. 


\section{Tissue Engineering in Alopecia}

Tissue engineering is an interdisciplinary field combining scaffolds, cells, and biomolecular signals to treat skin lesions. Its main challenge is the reconstitution of fully organized and functional organ systems from dissociated cells that have been propagated under a defined tissue culture condition. This strategy may contribute to the treatment of deep skin injuries and to the understanding of skin regeneration. Many dermal-epidermal composites or skin equivalents have been described to use in the clinic but the inability of these skin constructs to regenerate epidermal appendages, such as hair follicles, sebaceous, and sweat glands remains a major challenge [73-75].

Lee et al. developed a simplified procedure to reconstitute hair-producing skin (Table 4). They obtained epidermal and dermal cells from newborn mice, and mixed them in different ratios. A high-density cellular suspension was prepared in drops of minimal volume on tissue culture inserts or wells. They allowed the cells to settle until a gel consistency was obtained and they seeded the cells on the collagen beside a porous matrix of crosslinked bovine tendon collagen and glycosaminoglycan and a silicone layer. Both constructs were grafted in full thickness skin wounds generated on the back of athymic mice. Hair germ started to appear eight days after grafting, progressed to hair peg, and complete hair follicles were observed four days later. The skin was in good condition after a twelve-month follow-up [76]. Furthermore, two reports showed hair follicle neogenesis using hair germs obtained by the previously described "organ germ method" [77]. Asakawa et al. generated bioengineered hair germs mixing epithelial and mesenchymal cells derived from mouse embryos within a collagen gel drop, generating a structure (called "hair germ") with two cellular layers separated by a translucent region (Table 5). They observed the presence of mature hair follicles when these hair germs were transplanted ectopically into subrenal capsules. These bioengineered hair follicles had a normal histological structure with outer root sheath, inner root sheath, dermal papilla, hair matrix, and sebaceous glands and they were connected to the arrector pili muscle and nerve fibers and were able to produce hair shafts [78]. Toyoshima et al. also demonstrated fully functional orthotopic hair regeneration via intracutaneous transplantation of bioengineered hair follicle germs generated by epithelial and mesenchymal cells derived from mouse embryos [79]. Later, Qiao et al. showed a more developed morphological structure, called "proto hairs". It presented hair-like characteristics as an inner mass of cells similar to the dermal papilla structure, surrounded by matrix-like keratinocytes and a partially keratinized substance that could produce a hair shaft [80].

Table 4. Preclinical in vitro studies of Tissue Engineering for non-scarring alopecia.

\begin{tabular}{|c|c|c|c|c|c|}
\hline $\begin{array}{l}\text { Cell Types and } \\
\text { Scaffold }\end{array}$ & $\begin{array}{l}\text { Type of } \\
\text { Study }\end{array}$ & Experimental Design & Results & Conclusions & Reference \\
\hline $\begin{array}{l}\text { Human Dermal } \\
\text { Papilla (DP) } \\
\text { cells and } \\
\text { Keratinocytes } \\
\text { (KT) in type I } \\
\text { collagen matrix }\end{array}$ & $\begin{array}{l}\text { In vitro } \\
\text { study }\end{array}$ & $\begin{array}{l}\text { DP cells were isolated } \\
\text { from hair follicle of } \\
\text { human scalp. } \\
\text { Rat vibrissa DP cells } \\
\text { were isolated with } \\
\text { microdissection. } \\
\text { Keratinocytes were } \\
\text { isolated from normal } \\
\text { human skin. } \\
\text { Dermal equivalents were } \\
\text { prepared with type I } \\
\text { collagen extracted from } \\
\text { rat tail tendons. } \\
\text { Human dermal } \\
\text { fibroblasts or DP cells } \\
\text { were embedded in a } \\
\text { final concentration of } \\
1 \times 10^{5} \text { cells/mL } \\
\text { were added. } \\
\text { Keratinocytes were } \\
\text { seeded on the top of the } \\
\text { gel or embedded inside } \\
\text { the collagen matrix. }\end{array}$ & $\begin{array}{l}\text { 1-Human and rat vibrissa DP cells } \\
\text { were able to reorganize the } \\
\text { collagen lattices within the first } \\
48 \text { h. Contraction was } \\
\text { significantly stronger with rat } \\
\text { vibrissa DP cells than with human } \\
\text { DP cells ( } 60 \text { and } 40 \% \text {, } \\
\text { respectively). } \\
\text { 2-Addition of epidermal } \\
\text { keratinocytes enhanced } \\
\text { contraction in both cases (75 and } \\
56 \% \text {, respectively). } \\
\text { 3-After } 1 \text { week, rat vibrissa DP } \\
\text { cells cultured together with } \\
\text { keratinocytes totally } \\
\text { disaggregated and lysed } \\
\text { collagen lattices. } \\
\text { 4-Human DP cells reorganized } \\
\text { collagen matrix but were unable } \\
\text { to disintegrate it. } \\
\text { 5-After } 10 \text { days, DP cells } \\
\text { embedded into collagen gel, and } \\
\text { keratinocytes seeded on the top of } \\
\text { the gel formed tubular structures. }\end{array}$ & $\begin{array}{l}\text { 1-DP cells } \\
\text { induced } \\
\text { formation of } \\
\text { multicellular } \\
\text { tube-like } \\
\text { outgrowths in } \\
\text { the culture of } \\
\text { epidermal } \\
\text { keratinocytes }\end{array}$ & [81] \\
\hline
\end{tabular}


Table 4. Cont.

\begin{tabular}{|c|c|c|c|c|c|}
\hline $\begin{array}{l}\text { Cell Types and } \\
\text { Scaffold }\end{array}$ & $\begin{array}{l}\text { Type of } \\
\text { Study }\end{array}$ & Experimental Design & Results & Conclusions & Reference \\
\hline $\begin{array}{l}\text { Human dermal } \\
\text { papilla (DP) } \\
\text { cells cultured in } \\
\text { Matrigel }\end{array}$ & $\begin{array}{l}\text { In vitro } \\
\text { study }\end{array}$ & $\begin{array}{c}\text { Dermal cells were } \\
\text { isolated from dermal } \\
\text { papillae microdissected } \\
\text { from the bulbs of } \\
\text { dissected hair follicles. } \\
\text { Cells were seeded onto } \\
\text { wells precoated with } \\
\text { Matrigel or hyaluronan } \\
\text { or not. } \\
\text { For the formation of DP } \\
\text { spheroids in 3D Matrigel } \\
\text { culture, different } \\
\text { conditions were } \\
\text { evaluated. } \\
\text { All experiments, } \\
\text { characterization of } \\
\text { different culture } \\
\text { conditions was } \\
\text { conducted after } 5 \text { days } \\
\text { of harvesting. }\end{array}$ & $\begin{array}{l}\text { 1-When } 1 \times 10^{4} \text { DP cells were } \\
\text { cultured on the } 96 \text {-well plates } \\
\text { precoated with Matrigel for } 5 \\
\text { days, both passage } 2 \text { and passage } \\
8 \text { DP cells formed spheroidal } \\
\text { microtissues with a diameter of } \\
\text { 150-250 } \mu \text { m. } \\
\text { 2-Cells within DP spheres could } \\
\text { disaggregate and migrate out, } \\
\text { which was similar to primary DP. } \\
\text { 3-Expression of several genes and } \\
\text { proteins associated with hair } \\
\text { follicle inductivity of DP cells, } \\
\text { such as NCAM, Versican, and } \\
\alpha \text {-smooth muscle actin was } \\
\text { elevated in the spheres compared } \\
\text { with the dissociated DP cells. } \\
4 \text {-DP spheroids mixed with } \\
\text { HGMCs (hair germinal matrix } \\
\text { cells-commercial cell line) and } \\
\text { incubated on the Matrigel surface, } \\
\text { developed colourless hair shafts. }\end{array}$ & $\begin{array}{l}\text { 1-3D Matrigel } \\
\text { culture } \\
\text { technique is an } \\
\text { ideal culture } \\
\text { model for } \\
\text { forming DP } \\
\text { spheroids and } \\
\text { that sphere } \\
\text { formation } \\
\text { partially } \\
\text { models the } \\
\text { intact DP, } \\
\text { resulting in hair } \\
\text { induction, } \\
\text { even by } \\
\text { high-passage } \\
\text { DP cells. }\end{array}$ & [82] \\
\hline
\end{tabular}

Table 5. Preclinical in vivo studies of Tissue Engineering for non-scarring alopecia.

\begin{tabular}{|c|c|c|c|c|c|}
\hline $\begin{array}{l}\text { Cell Types and } \\
\text { Scaffold }\end{array}$ & Type of Study & Experimental Design & Results & Conclusions & Reference \\
\hline $\begin{array}{l}\text { Mouse epidermal } \\
\text { and dermal cells } \\
\text { in a gel-like } \\
\text { endogenous } \\
\text { matrix or in } \\
\text { Integra }{ }^{\mathrm{TM}} \text { Bilayer } \\
\text { Wound Matrix }\end{array}$ & $\begin{array}{l}\text { In vivo study } \\
\text { Athymic nude, } \\
\text { hairy SCID, or } \\
\text { normal mice of } \\
\text { the same } \\
\text { inbred strain }\end{array}$ & $\begin{array}{c}\text { Dissociated new-born } \\
\text { mouse epidermal and } \\
\text { dermal stem cell were mixed } \\
\text { in different ratios. } \\
\text { For gel-like endogenous } \\
\text { matrix: } 150-200 \mu \mathrm{L} \text { of cell } \\
\text { suspension, containing } 2-20 \\
\text { million cells, was pipetted } \\
\text { onto a tissue cell culture } \\
\text { insert. } \\
\text { For each } 1.5 \mathrm{~cm}^{2} \text { piece of } \\
\text { Integra, } 12 \text { million } \\
\text { epidermal cells and } 60 \\
\text { million dermal cells in } 200 \\
\mu \mathrm{L} \text { of serum-free medium. } \\
\text { The intended area of skin to } \\
\text { be grafted for hair bearing } \\
\text { was excised in full thickness. }\end{array}$ & $\begin{array}{l}\text { 1-At day } 8 \text {, hair germs } \\
\text { started to appear, which } \\
\text { progress to the hair peg } \\
\text { stage at about day } 9 . \\
\text { 2-Hairs can be seen on } \\
\text { the surface of the wound } \\
\text { as early as 11-15 days } \\
\text { postgraft. } \\
\text { 3-Histological sections of } \\
\text { the skin at day } 11 \\
\text { postgraft showed that } \\
\text { normal layers of the skin } \\
\text { were regenerated. } \\
\text { 4-after hairs were } \\
\text { clipped or plucked, they } \\
\text { grew and reached } \\
\text { normal length in about } \\
2 \text { months. }\end{array}$ & $\begin{array}{l}\text { 1-Ratio of } \\
\text { 1:5-10 for } \\
\text { epidermal:dermal } \\
\text { cells is optimal. } \\
\text { 2-There are no } \\
\text { differences of } \\
\text { skin quality or } \\
\text { hair growth } \\
\text { when tissue } \\
\text { culture inserts or } \\
\text { Integra }{ }^{\mathrm{TM}} \\
\text { are used. } \\
\text { 3-After } \\
\text { 18 months, hair } \\
\text { growth and } \\
\text { cycling are active. }\end{array}$ & [76] \\
\hline $\begin{array}{c}\text { Mouse } \\
\text { embryonic } \\
\text { epithelial and } \\
\text { dermal cells } \\
\text { using the organ } \\
\text { germ method. } \\
\text { Collagen gel }\end{array}$ & $\begin{array}{c}\text { In vivo study } \\
\text {-C57BL/6 mice } \\
\text {-C57BL/6-TgN } \\
\text { (act-EGFP) } \\
\text { mice } \\
\text {-C57BL/6-TgN } \\
\text { (act-EGFP) } \\
\text { OsbC14-Y01- } \\
\text { FM131 mice } \\
\text {-Balb/c nu/nu } \\
\text { mice }\end{array}$ & $\begin{array}{c}\text { Bioengineered hair follicle } \\
\text { germs: } 7.5 \times 10^{4} \text { epithelial } \\
\text { cells and } 7.5 \times 10^{4} \\
\text { mesenchymal cells which } \\
\text { were derived from skin from } \\
\text { C57BL/6-TgN (act-EGFP) } \\
\text { mouse embryos. } \\
\text { After } 2 \text { days in culture, to } \\
\text { develop and mature } \\
\text { bioengineered hair follicles, } \\
\text { they were transplanted into } \\
\text { the sub-renal capsules of } \\
\text { 8-week-old C57BL/6 mice } \\
\text { At } 14 \text { days after engraftment, } \\
\text { mature bioengineered hair } \\
\text { follicles were harvested and } \\
\text { dissected into a single or a } \\
\text { couple of follicular units via } \\
\text { stereomicroscopic } \\
\text { observation. } \\
\text { Mature bioengineered hair } \\
\text { follicles were } \\
\text { intracutaneously grafted } \\
\text { into Balb/c nu/nu mice. }\end{array}$ & $\begin{array}{l}\text { 1-After } 7 \text { to } 10 \text { days after } \\
\text { the orthotopic } \\
\text { transplantation, the } \\
\text { wound was } \\
\text { completely healed. } \\
\text { 2-The eruption of the } \\
\text { bioengineered pelage } \\
\text { shaft was observed at } 14 \\
\pm 1.8(n=30) \text { days at a } \\
\text { frequency of } 90 \%(n=33) \\
\text { 3-The bioengineered } \\
\text { hairs repeatedly } \\
\text { exhibited growth } \\
\text { and regression. } \\
\text { 4-The periods of growth } \\
\text { and regression of } \\
\text { bioengineered hair } \\
\text { follicles lasted } 11.0( \pm 2.6) \\
\text { days and } 9.4( \pm 2.4) \text { days, } \\
\text { respectively. }\end{array}$ & $\begin{array}{l}\text { 1-Bioengineered } \\
\text { hair follicles } \\
\text { generated by } \\
\text { ectopic } \\
\text { transplantation } \\
\text { can functionally } \\
\text { replace } \\
\text { orthotopic FUT } \\
\text { therapy. } \\
\text { 2-Ectopic } \\
\text { bioengineered } \\
\text { pelage follicle } \\
\text { connected to the } \\
\text { epidermal layer } \\
\text { of the skin, } \\
\text { reproduced the } \\
\text { stem cell niche } \\
\text { and the hair cycle } \\
\text { equivalent to the } \\
\text { natural pelage, } \\
\text { and repeatedly } \\
\text { produced the } \\
\text { same hair types } \\
\text { during the hair } \\
\text { cycles. }\end{array}$ & [78] \\
\hline
\end{tabular}


Table 5. Cont.

\begin{tabular}{|c|c|c|c|c|c|}
\hline $\begin{array}{l}\text { Cell Types and } \\
\text { Scaffold }\end{array}$ & Type of Study & Experimental Design & Results & Conclusions & Reference \\
\hline $\begin{array}{c}\text { Mouse } \\
\text { embryonic skin } \\
\text { epithelial and } \\
\text { mesenchymal } \\
\text { cells. Epithelial } \\
\text { cells from adult } \\
\text { vibrissa-derived } \\
\text { bulge region and } \\
\text { primary cultured } \\
\text { dermal papilla } \\
\text { (DP) cells. } \\
\text { Collagen gel }\end{array}$ & $\begin{array}{c}\text { In vivo study } \\
\text {-C57BL/6 } \\
\text {-C57BL/6-TgN } \\
\text { (act-EGFP) } \\
\text { OsbC14-Y01- } \\
\text { FM131 mice } \\
\text {-Balb/c nu/nu } \\
\text { mice }\end{array}$ & $\begin{array}{l}\text { The bioengineered pelage } \\
\text { follicle germs: mouse } \\
\text { embryonic skin epithelial } \\
\text { and mesenchymal cells ( } 7.5 \\
\times 10^{3} \text { of each cell type) } \\
\text { The bioengineered vibrissae } \\
\text { follicle germ: epithelial cells } \\
\left(1 \times 10^{4} \text { cells) isolated from }\right. \\
\text { the adult vibrissae-derived } \\
\text { bulge region and primary } \\
\text { cultured DP cells ( } 3 \times 10^{3} \\
\text { cells) } \\
\text { Bioengineered hair germs } \\
\text { were ectopically engrafted } \\
\text { into the sub-renal capsules } \\
\text { of C57BL/ } 6 \text { mice or } \\
\text { intracutaneously } \\
\text { transplanted onto the back } \\
\text { of Balb/c mice. }\end{array}$ & $\begin{array}{l}\text { 1-Eruption and growth } \\
\text { hair shafts were } \\
\text { observed at a frequency } \\
\text { of } 94 \%(n=78) \text { and } \\
74 \%(n=62) \text { for } \\
\text { bioengineered pelage } \\
\text { and vibrissae follicles, } \\
\text { respectively. } \\
\text { 2-Bioengineered pelage } \\
\text { follicle and the vibrissae } \\
\text { follicle formed correct } \\
\text { structures comprising an } \\
\text { infundibulum and } \\
\text { sebaceous gland in the } \\
\text { proximal region. } \\
\text { 3-Bioengineered pelage } \\
\text { follicle germs were } \\
\text { found to produce all } \\
\text { types of pelage hairs. } \\
4 \text {-The bioengineered } \\
\text { pelage and vibrissae } \\
\text { follicles repeated the hair } \\
\text { cycle at least } 3 \text { times } \\
\text { during the } \\
\text { 80-day period. }\end{array}$ & $\begin{array}{l}\text { 1-Both } \\
\text { bioengineered } \\
\text { hair follicles } \\
\text { produce follicles } \\
\text { that can repeat } \\
\text { the hair cycle, } \\
\text { connect properly } \\
\text { with surrounding } \\
\text { skin tissues and } \\
\text { achieve } \\
\text { piloerection. }\end{array}$ & [79] \\
\hline $\begin{array}{l}\text { Human Dermal } \\
\text { Papilla (DP) cells } \\
\text { and } \\
\text { Keratinocytes } \\
\text { (KT) in collagen- } \\
\text { glycosaminoglycan } \\
\text { scaffolds }\end{array}$ & In vivo study & $\begin{array}{c}\text { Human or murine DP cells, } \\
\text { combined with } \\
\text { foreskin-derived } \\
\text { keratinocytes (KT) or } \\
\text { transduced KT with } \\
\text { pBABE-puro encoding } \\
\text { N-terminally truncated } \\
\text { 3-catenin (KT') (expression } \\
\text { induced by } \\
\text { hydroxytamoxifen (4OHT) } \\
\text { administration) } \\
\text { A positive control fabricated } \\
\text { with murine hair from } \\
\text { newborn cells was } \\
\text { also evaluated. } \\
\text { After } 10 \text { days incubation at } \\
\text { air-liquid interface, } \\
\text { Engineering Skin Substitutes } \\
\text { (ESS) were grafted to } \\
\text { athymic mice and were } \\
\text { evaluated for } 6 \text { weeks. }\end{array}$ & $\begin{array}{c}\text { 1-EF1 and WNT10B were } \\
\text { significantly higher in } \\
\text { 4OHT-treated ESS } \\
\text { compared with } \\
\text { vehicle-treated ESS but } \\
\text { no hairs were observed } \\
\text { in ESS with KTs' and } \\
\text { hDP cells. } \\
\text { 2-Only ESS with mDP } \\
\text { cells formed follicular } \\
\text { structures, as confirmed } \\
\text { by trichohyalin and } \\
\text { keratin } 10 \\
\text { immunostaining. }\end{array}$ & $\begin{array}{l}\text { 1-Chimeric hair } \\
\text { follicles were } \\
\text { successfully } \\
\text { generated in ESS } \\
\text { containing } \\
\text { combinations of } \\
\text { mDP cells and } \\
\text { KTs or KTs', } \\
\text { although they } \\
\text { were deficient } \\
\text { anatomically. } \\
\text { 2-DP cells play } \\
\text { an important role } \\
\text { in the induction } \\
\text { of hair } \\
\text { morphogenesis } \\
\text { in ESS. }\end{array}$ & [83] \\
\hline
\end{tabular}


Table 5. Cont

\begin{tabular}{|c|c|c|c|c|c|}
\hline $\begin{array}{l}\text { Cell Types and } \\
\text { Scaffold }\end{array}$ & Type of Study & Experimental Design & Results & Conclusions & Reference \\
\hline $\begin{array}{l}\text { Mouse Dermal } \\
\text { Papilla (DP) cells } \\
\text { and human } \\
\text { keratinocytes in } \\
\text { grafting } \\
\text { chambers }\end{array}$ & $\begin{array}{l}\text { In vivo study } \\
\text {-Versican-GFP } \\
\text { transgenic mice } \\
\text {-Nude mice } \\
\text { (bulb/c, nu/nu) }\end{array}$ & $\begin{array}{l}\text { DP cells were isolated from } \\
\text { skin of Versican-GPF } \\
\text { transgenic mice. } \\
\text { Keratinocytes were isolated } \\
\text { from human scalps tissues } \\
\text { and neonatal foreskins. } \\
\text { Human epidermal cells and } \\
\text { DP cell fractions (containing } \\
1 \times 10^{6}-10^{7} \text { cells of each) } \\
\text { were transferred to grafting } \\
\text { chambers implanted on the } \\
\text { dorsal skins of nude mice } \\
\text { (bulb/c, nu/nu). } \\
\text { Chambers were removed } \\
1 \text { week after grafting, and } \\
\text { hair follicle formation was } \\
\text { assessed at 3-4 weeks. }\end{array}$ & $\begin{array}{l}\text { 1-DP cells were able to } \\
\text { induce hair follicles } \\
\text { together with the } \\
\text { epidermal component } \\
\text { but only when both } \\
\text { epithelial and } \\
\text { mesenchymal } \\
\text { components were } \\
\text { present. Hair pegs were } \\
\text { formed a week } \\
\text { after grafting. } \\
\text { 2-When the number of } \\
\text { epidermal cells was } \\
\text { reduced to } 1 \times 10^{6} \text { cells } \\
\text { (10\% of DP cells), the } \\
\text { efficiency of hair follicle } \\
\text { reconstitution was } \\
\text { mostly unchanged. } \\
\text { 3-When human } \\
\text { keratinocytes were } \\
\text { included, hair } \\
\text { follicle-like structures } \\
\text { were formed at the graft } \\
\text { sites } 4 \text { weeks later and } \\
\text { innermost regions of the } \\
\text { structures were clearly } \\
\text { keratinized. } \\
\text { 4-Human adult cells also } \\
\text { have the same ability to } \\
\text { differentiate into } \\
\text { follicular keratinocytes } \\
\text { as neonatal } \\
\text { foreskin-derived } \\
\text { epidermal cells. }\end{array}$ & $\begin{array}{l}\text { 1-Results show } \\
\text { that hair } \\
\text { follicle-like } \\
\text { structures } \\
\text { consisting of } \\
\text { human } \\
\text { keratinocytes and } \\
\text { murine } \\
\text { mesenchymal } \\
\text { cells are } \\
\text { generated. } \\
\text { 2-Epithelial- } \\
\text { mesenchymal } \\
\text { interactions } \\
\text { exists between } \\
\text { human and } \\
\text { mouse cells. }\end{array}$ & [84] \\
\hline $\begin{array}{l}\text { Mouse dermal } \\
\text { and human } \\
\text { epidermal cells. } \\
\text { Patch assay }\end{array}$ & In vivo study & $\begin{array}{c}\text { Mouse dermal and } \\
\text { epidermal cells were freshly } \\
\text { isolated from C57BL/6 used } \\
\text { for control experiments. } \\
\text { Human dermal papilla (DP) } \\
\text { spheres }\left(10^{4} \text { cells) were }\right. \\
\text { prepared from } \\
\text { two-dimensional (2D) } \\
\text { cultured DP cells using } \\
\text { either low cell-binding plate } \\
\text { or hydrocell plate and } \\
\text { combined with freshly } \\
\text { isolated mouse epidermal } \\
\text { cells for implantation } \\
\text { A total of } 200 \text { DP spheres } \\
\left(2 \times 10^{6} \text { cells) prepared from }\right. \\
\text { human DP cells were mixed } \\
\text { with fresh mouse epidermal } \\
\text { cells ( } 2 \times 10^{6} \text { cells) and } \\
\text { implanted. } \\
50 \text { DP spheres ( } 5 \times 10^{5} \text { cells) } \\
\text { prepared from human DP } \\
\text { cells were mixed with fresh } \\
\text { mouse epidermal cells }(5 \times \\
10^{5} \text { cells) and implanted. } \\
\text { Mice were killed } 2 \text { weeks } \\
\text { after cell implantation in } \\
\text { order to verify hair follicle } \\
\text { induction. }\end{array}$ & $\begin{array}{l}\text { 1-Hair follicle was } \\
\text { observed in positive } \\
\text { control experiments with } \\
\text { mouse dermal and } \\
\text { epidermal cells. } \\
\text { 2-Hair follicle formation } \\
\text { was observed when } \\
\text { human DP spheres from } \\
\text { various passages of } \\
\text { culture were mixed with } \\
\text { new born mouse } \\
\text { epidermal cells. } \\
\text { 3-Hair follicles were } \\
\text { never observed when 2D } \\
\text { cultures from the same } \\
\text { population were use } \\
\text { 4-The morphology and } \\
\text { size of hair follicles } \\
\text { induced by human DP } \\
\text { spheres resembled the } \\
\text { ones induced by mouse } \\
\text { dermal cells. }\end{array}$ & $\begin{array}{l}\text { 1-Using a } \\
\text { reconstitution } \\
\text { assay, sphere } \\
\text { formation } \\
\text { increases the } \\
\text { ability of } \\
\text { cultured human } \\
\text { DP cells to induce } \\
\text { hair follicles from } \\
\text { mouse epidermal } \\
\text { cells }\end{array}$ & [85] \\
\hline
\end{tabular}


Table 5. Cont.

\begin{tabular}{|c|c|c|c|c|c|}
\hline $\begin{array}{l}\text { Cell Types and } \\
\text { Scaffold }\end{array}$ & Type of Study & Experimental Design & Results & Conclusions & Reference \\
\hline $\begin{array}{l}\text { Human Dermal } \\
\text { Papilla (DP) cells } \\
\text { embedded into } \\
\text { rat tail collagen } \\
\text { type } 1 \text { and } \\
\text { neonatal foreskin } \\
\text { keratinocytes } \\
\text { (NFK) } \\
\text { Dermal-epidermal } \\
\text { composites } \\
\text { (DEC) }\end{array}$ & $\begin{array}{l}\text { In vivo study } \\
\text {-Nude mice }\end{array}$ & $\begin{array}{c}\text { Human DP cells were } \\
\text { isolated from temporal scalp } \\
\text { dermis. } \\
\text { DECs were constructed by } \\
\text { combining DP cells with rat } \\
\text { tail collagen type 1, adding } \\
\text { NFKs on top and bringing } \\
\text { the constructs to the } \\
\text { air-liquid interface for } 2 \\
\text { days before grafting onto } \\
\text { female nude mice. }\end{array}$ & $\begin{array}{l}\text { 1-Alkaline phosphatase } \\
\text { activity was variable } \\
\text { between samples, with } \\
\text { cells from } 3 \text { of the } \\
\text { donors showing alkaline } \\
\text { phosphatase activity in } \\
\text { more than } 50 \% \text { of } \\
\text { the cells. } \\
\text { 2-8 weeks after grafting, } \\
\text { hair follicles (HFs) were } \\
\text { observed in mice grafted } \\
\text { with the } 3 \text { human DP } \\
\text { cells with higher alkaline } \\
\text { phosphatase activity. } \\
\text { 3-HFs had a bulb, } \\
\text { dermal sheath, hair } \\
\text { matrix and cortex } \\
\text { 4-Cells in the region of } \\
\text { the DP and displayed } \\
\text { alkaline phosphatase } \\
\text { activity, normal } \\
\text { reactivity with specific } \\
\text { antibodies to human } \\
\text { nestin and versican. } \\
\text { 5-Basal layer of the outer } \\
\text { root sheath was } \\
\text { immunoreactive for } \\
\text { keratin } 15 \text {. }\end{array}$ & $\begin{array}{c}\text { 1-Cultured } \\
\text { specialized } \\
\text { human cells such } \\
\text { as DP cells can } \\
\text { induce complete } \\
\text { pilosebaceous } \\
\text { units in vivo in } \\
\text { the grafted DEC } \\
\text { model. }\end{array}$ & [86] \\
\hline
\end{tabular}

After that, Osada et al. artificially prepared dermal papilla cells spheres by aggregation of mouse vibrissae follicles in a round-bottom 96-well low-binding plate (Table 6). These spheres expressed higher amounts of versican, an anagen dermal papilla marker, than dermal papilla cells in monolayer cultures and they induced hair follicle neogenesis for at least twenty-six passages. However, these methods obtain variable sizes of microtissues and cell number content. To resolve this problem, substratum materials to enhance dermal papillae cells aggregation, such as polyethylene-co-vinyl alcohol or polyvinyl alcohol membranes, were employed, inducing hair follicular neogenesis [87-89]. 
Table 6. Preclinical in vitro and in vivo studies of Tissue Engineering for non-scarring alopecia.

\begin{tabular}{|c|c|c|c|c|c|}
\hline $\begin{array}{l}\text { Cell Types and } \\
\text { Scaffold }\end{array}$ & Type of Study & Experimental Design & Results & Conclusions & Reference \\
\hline \multirow[t]{2}{*}{$\begin{array}{l}\text { Mouse } \\
\text { embryonic skin } \\
\text { epidermal and } \\
\text { dermal cells. } \\
\text { Cell aggregates }\end{array}$} & $\begin{array}{l}\text { In vitro and } \\
\text { in vivo study } \\
\text {-C57BL/6 mice } \\
\text {-Male CD-1 } \\
\text { nude albino } \\
\text { mice }\end{array}$ & $\begin{array}{c}\text { Mixed dermal and epidermal } \\
\text { cells (keratinocytes and } \\
\text { melanocytes) } \\
\text { were removed from } \\
\text { embryonic day } 18 \\
\text { C57BL/6 mice. } \\
\text { Aggregates were formed using } \\
\text { the hanging droplet method. } 2 \\
\times 10^{6} \text { cells/mL were hanging } \\
\text { droplet in } 20 \text { } \mu \text { L. Aggregate } \\
\text { formation was completed } \\
\text { within } 18-20 \text { h. } \\
\text { To form proto-hairs, } \\
\text { aggregates were transferred } \\
\text { individually to wells of a } \\
\text { 96-well round-bottom plate. } \\
\text { Wells were precoated with } \\
\text { 0.24\% methylcellulose } \\
\text { medium to prevent adherence } \\
\text { of proto-hairs. } \\
\text { A single cultured aggregate } \\
\text { (proto-hair) was grafted into } \\
\text { the ear of male CD-1 } \\
\text { nude mice. } \\
\text { Regrowth of neo-generated } \\
\text { hairs was regularly monitored. }\end{array}$ & $\begin{array}{l}\text { 1-Few days after } \\
\text { aggregate formation } \\
\text { (4-7 days), hair-like } \\
\text { structures } \\
\text { started forming. } \\
\text { 2-The frequency of hair } \\
\text { morphogenesis ranged } \\
\text { from } 66 \text { to } 100 \% \text { among } \\
\text { numerous experiments. } \\
\text { 3-Proto-hairs could } \\
\text { undergo further } \\
\text { maturation in vivo. } \\
\text { 4-Within } 2 \text { weeks, } \\
\text { black-pigmented hair } \\
\text { fibres appeared. } \\
\text { 5-Within } 4 \text { weeks after } \\
\text { implantation, } \\
\text { approximately } 50-60 \% \\
\text { of implants developed } \\
\text { follicles with pigmented } \\
\text { hair shafts. } \\
\text { 6-Hairs developed from } \\
\text { implanted proto-hairs } \\
\text { were well anchored in } \\
\text { the skin and persisted } \\
\text { for at least } 6 \text { months } \\
\text { 7-Implanted proto-hairs } \\
\text { were able to maintain } \\
\text { their growth for } \\
\text { many months. }\end{array}$ & $\begin{array}{l}\text { 1-In vitro } \\
\text { incubation of } \\
\text { mixed follicular } \\
\text { cell aggregates } \\
\text { leads to the } \\
\text { formation of } \\
\text { partially } \\
\text { developed } \\
\text { follicle-like } \\
\text { structures called } \\
\text { proto-hairs. } \\
\text { 2-Upon } \\
\text { implantation, } \\
\text { proto-hairs fully } \\
\text { develop into } \\
\text { normal hairs that } \\
\text { persist and grow } \\
\text { indefinitely. }\end{array}$ & [80] \\
\hline & & $\begin{array}{l}\text { DP cells were dissected from } \\
\text { mouse vibrissae follicles } \\
\text { (versican-GFP-Tg) and } 10^{4} \mathrm{DP} \\
\text { cells were aggregated to form } \\
\text { one spherical structure and } \\
\text { maintained for } 2 \text { to } 12 \text { days. } \\
\text { Epidermal and DP cells were } \\
\text { dissected from } \\
\text { C57BL/6J mouse. } \\
\text { Fifty of the DP spheres or } \\
5 \times 10^{5} \text { of the dissociated } \\
\text { DP cells } \\
\text { were combined with } 5 \times 10^{5} \\
\text { epidermal cells. } \\
\text { Cells were injected } \\
\text { subcutaneously into athymic } \\
\text { nude mice. } \\
\text { Mice were killed } 2 \text { weeks after } \\
\text { cellimplantation to verify hair } \\
\text { follicle induction }\end{array}$ & $\begin{array}{l}\text { 1-Hair follicle induction } \\
\text { could occur even from } \\
\text { DPspheres of cells after } \\
26 \text { passages } \\
\text { 2-DP cell suspensions } \\
\text { from more than } 8 \\
\text { passages, however, } \\
\text { could not induce hair } \\
\text { follicles. }\end{array}$ & $\begin{array}{l}\text { 1-DP have highly } \\
\text { aggregative } \\
\text { properties } \\
\text { compared } \\
\text { withskin } \\
\text { fibroblasts } \\
\text { 2-DP spheres } \\
\text { may have } \\
\text { recovered their } \\
\text { aggregative } \\
\text { property by } \\
\text { increasing their } \\
\text { versican content, } \\
\text { which helped } \\
\text { them to interact } \\
\text { with epidermal } \\
\text { cells and induce } \\
\text { hair follicles. }\end{array}$ & [87] \\
\hline
\end{tabular}


Table 6. Cont

\begin{tabular}{|c|c|c|c|c|c|}
\hline $\begin{array}{l}\text { Cell Types and } \\
\text { Scaffold }\end{array}$ & Type of Study & Experimental Design & Results & Conclusions & Reference \\
\hline \multirow{2}{*}{$\begin{array}{c}\text { Mouse, rat and } \\
\text { human Dermal } \\
\text { Papilla (DP) } \\
\text { cells. } \\
\text { Spheres }\end{array}$} & \multirow{2}{*}{$\begin{array}{c}\text { In vitro and } \\
\text { in vivo studies } \\
\text {-Versican-GFP- } \\
\text { transgenic } \\
\text { (versican-GFP- } \\
\text { Tg) mice } \\
\text {-C57BL/6J } \\
\text {-Wistar rats } \\
\text {-Athymic } \\
\text { nude mice }\end{array}$} & $\begin{array}{c}\text { DP cells were isolated } \\
\text { by scissors and forceps from } \\
\text { cheeks of Wistar rats- } \\
10^{4}, 2 \times 10^{4}, 4 \times 10^{4}, 8 \times 10^{4} \\
\text { and } 1.6 \times 10^{5} \text { cells were added } \\
\text { to each well, containing } \\
\text { poly-(ethylene-co-vinyl } \\
\text { alcohol) (EVAL). } \\
\text { DP microtissues were } \\
\text { characterized in vitro and } \\
\text { In vivo. }\end{array}$ & $\begin{array}{l}\text { 1-Formation of DP } \\
\text { microtissues on EVAL is } \\
\text { affected by seeding } \\
\text { cell numbers. } \\
\text { 2-After } 5 \text { days of culture, } \\
\text { dense microtissues were } \\
\text { observed on EVAL at the } \\
\text { seeding numbers of } \\
8 \times 10^{4} \text { cells/well } \\
\text { or higher. } \\
\text { 3-About } 47 \text { microtissues } \\
\text { (diameter }>125 \text { mm) } \\
\text { were } \\
\text { obtained on an EVAL } \\
\text { surface of } 1.9 \text { cm }{ }^{2} \text { with a } \\
\text { single seeding of } \\
1.6 \times 10^{5} \text { DP cells. } \\
4 \text {-Microtissues had a } \\
\text { spheroidal structure. } \\
5 \text {-Cell viability in DP } \\
\text { microtissues on EVAL is } \\
\text { much higher than that in } \\
\text { DP spheroids generated } \\
\text { by hanging } \\
\text { drop method. }\end{array}$ & $\begin{array}{l}\text { 1-Self-assembly } \\
\text { of DP cells into } \\
\text { spheroidal } \\
\text { inductive } \\
\text { microtissues } \\
\text { can be facilitated } \\
\text { when cells are } \\
\text { seeded at } \\
\text { appropriate } \\
\text { densities on } \\
\text { EVAL surface. } \\
\text { 2- DP } \\
\text { microtissues } \\
\text { mixed with } \\
\text { newborn mouse } \\
\text { epidermal cells } \\
\text { and injected into } \\
\text { the hypodermis } \\
\text { of nude mice are } \\
\text { able to induce } \\
\text { new hair follicles } \\
\text { (HFs). }\end{array}$ & [88] \\
\hline & & $\begin{array}{l}\text { Human DP cells were isolated } \\
\text { from scalp tissues obtained } \\
\text { from plastic surgery. } \\
\text { Human DPCs were expanded } \\
\text { under conditions of activation } \\
\text { of the Wnt/ } \beta \text {-catenin } \\
\text { signalling pathway } \\
\text { (GSK-3 inhibitor, } \\
\text { 6-bromoindirubin-3'-oxime } \\
\text { (BIO)). } \\
\text { hDP cells were analysed in the } \\
\text { presence or absence of BIO. } \\
\text { A cellular grafting assay to } \\
\text { evaluate the hair-inducing } \\
\text { ability of cultured human DP } \\
\text { cells ( } 5 \times 10^{6} \text { cells/grafting) } \\
\text { was engrafted on the dorsal } \\
\text { skins of nude mice } \\
\text { (bulb/c, nu/nu) }\end{array}$ & $\begin{array}{l}\text { 1-Protein level of LEF1 in } \\
\text { BIO-treated hDP cells } \\
\text { showed a } 2.7 \text {-fold } \\
\text { increase compared with } \\
\text { that without BIO. } \\
\text { 2-Nuclear } \beta \text {-catenin was } \\
\text { evidently observed in } \\
\text { BIO-treated human } \\
\text { DP cells } \\
\text { 3-Human DP cells } \\
\text { cultured in the presence } \\
\text { of BIO and transplanted } \\
\text { with murine epidermal } \\
\text { cell fraction, formed hair } \\
\text { follicle-like structures. }\end{array}$ & $\begin{array}{l}\text { 1-Human DP } \\
\text { cells cultured } \\
\text { under } \\
\text { Wnt/ } \beta \text {-catenin } \\
\text { signalling } \\
\text { activation by } \\
\text { GSK-3 } \beta \\
\text { inhibition } \\
\text { maintained the } \\
\text { expression level } \\
\text { of DP marker } \\
\text { genes. } \\
\text { 2-Human DP } \\
\text { cells showed } \\
\text { constant hair } \\
\text { induction when } \\
\text { transplanted } \\
\text { with murine } \\
\text { epidermal cell } \\
\text { fraction. }\end{array}$ & [89] \\
\hline
\end{tabular}


Table 6. Cont.

\begin{tabular}{|c|c|c|c|c|c|}
\hline $\begin{array}{l}\text { Cell Types and } \\
\text { Scaffold }\end{array}$ & Type of Study & Experimental Design & Results & Conclusions & Reference \\
\hline $\begin{array}{l}\text { Primary human } \\
\text { interfollicular } \\
\text { dermal } \\
\text { fibroblasts, hair } \\
\text { follicle dermal } \\
\text { papilla, or hair } \\
\text { follicle dermal } \\
\text { sheath cells into } \\
\text { rat tail collagen } \\
\text { and human } \\
\text { keratinocytes }\end{array}$ & $\begin{array}{l}\text { In vitro and } \\
\text { in vivo studies } \\
\text {-SCID mouse }\end{array}$ & $\begin{array}{c}\text { Cells were isolated from } \\
\text { occipital scalp } \\
\text { In vitro } \\
\text { Constructs of collagen were } \\
\text { established in parallel from } \\
\text { fibroblasts, dermal papilla } \\
\text { cells and dermal sheath cells. } \\
\text { After } 7 \text { days, keratinocytes } \\
\text { added and cultured for } \\
17 \text { days. } \\
\text { In vivo } \\
\text { Dermal fibroblasts, dermal } \\
\text { papilla cells, dermal sheath } \\
\text { cells and keratinocytes } \\
\text { were trypsinized. } \\
\text { 107 million keratinocytes were } \\
\text { then combined with either } 10^{7} \\
\text { fibroblasts, or } 10^{7} \text { dermal } \\
\text { papilla cells and pipetted into } \\
\text { a hole located on a silicone } \\
\text { chamber previously } \\
\text { implanted under de dorsal } \\
\text { skin of a SCID mouse. } \\
\text { After one week the silicone } \\
\text { chamber was removed, and } \\
\text { cells were left for a further } \\
\text { two weeks. }\end{array}$ & $\begin{array}{c}\text { In vitro } \\
\text { 1-There were no obvious } \\
\text { differences in the } \\
\text { equivalents containing } \\
\text { hair follicle dermal cells, } \\
\text { when compared to a } \\
\text { fibroblast support layer. } \\
\text { 2-Hair follicle dermal } \\
\text { cells were capable of } \\
\text { supporting growth and } \\
\text { differentiation of } \\
\text { overlying } \\
\text { epidermal cells. } \\
\text { 3-Type IV collagen } \\
\text { (COL4) labeling was } \\
\text { most intense in the } \\
\text { basement membrane of } \\
\text { constructs supported by } \\
\text { dermal sheath cells from } \\
\text { the hair follicle. } \\
\text { In vivo } \\
\text { 1-After grafting, all } \\
\text { mixed cells were } \\
\text { organized to form a } \\
\text { skin structure. } \\
\text { After } 3 \text { weeks, cells had } \\
\text { reorganized with dermal } \\
\text { cells on the inner surface, } \\
\text { and keratinocytes } \\
\text { exposed to the external } \\
\text { air interface }\end{array}$ & $\begin{array}{l}\text { 1-Human hair } \\
\text { follicle dermal } \\
\text { cells can be } \\
\text { readily } \\
\text { interchanged } \\
\text { with } \\
\text { interfollicular } \\
\text { fibroblasts and } \\
\text { used as an } \\
\text { alternative cell } \\
\text { source for } \\
\text { establishing the } \\
\text { dermal } \\
\text { component of } \\
\text { engineered skin } \\
\text { both in vitro and } \\
\text { in vivo. }\end{array}$ & {$[90,91]$} \\
\hline $\begin{array}{l}\text { Human dermal } \\
\text { papilla (DP) } \\
\text { and dermal } \\
\text { sheath (DS) } \\
\text { cells and } \\
\text { epithelial cells } \\
\text { into collagen } \\
\text { gel. } \\
\text { Organotypic } \\
\text { culture }\end{array}$ & $\begin{array}{l}\text { In vitro and } \\
\text { in vivo study } \\
\text {-Nude mice }\end{array}$ & $\begin{array}{l}\text { DP cells and DS cells of the } \\
\text { human hair follicles (HFs) } \\
\text { were isolated from } \\
\text { human scalp. } \\
\text { Dermal fibroblast (FB) from } \\
\text { the scalp skin or foreskin was } \\
\text { cultured separately as } \\
\text { routine method. } \\
\text { Keratinocytes from } \\
\text { interfollicular and follicle } \\
\text { outer root sheath (ORS } \\
\text { superior or inferior) were also } \\
\text { isolated from human scalp. } \\
\text { DP cells, DS cells or FBs were } \\
\text { embedded onto collagen gel } \\
\text { and } 5 \times 10^{5} \text { epithelial cells } \\
\text { were plated on the prepared } \\
\text { mesenchymal cell-populated } \\
\text { collagen gels } \\
\text { (Organotypic culture). } \\
\text { Gels were immersed for } \\
2 \text { weeks and then were } \\
\text { transplanted on the dorsal } \\
\text { skin of the nude mice for } \\
1 \text { month. }\end{array}$ & $\begin{array}{l}\text { 1-Compared with the } \\
\text { free cell-populated gels, } \\
\text { on the four types of } \\
\text { mesenchymal } \\
\text { cell-populated gels, the } \\
\text { growth, differentiation } \\
\text { and shape of } \\
\text { interfollicular } \\
\text { keratinocytes and ORS } \\
\text { epithelial cells were } \\
\text { remarkably improved. } \\
\text { 2-Epidermal structure } \\
\text { reformed by the } \\
\text { interfollicular } \\
\text { keratinocytes on four } \\
\text { types of mesenchymal } \\
\text { cell-populated was } \\
\text { differentiated very well } \\
\text { and was similar to the } \\
\text { epidermis of nature } \\
\text { live skin. } \\
\text { 3-Epidermis reformed by } \\
\text { the superior ORS cells } \\
\text { and the interfollicular } \\
\text { keratinocytes was the } \\
\text { thickest while the } \\
\text { epidermis reformed only } \\
\text { 3-4 layers by the bulb } \\
\text { matrical cells was } \\
\text { the thinnest. } \\
\text { 4-In the organotypic } \\
\text { culture of superior + DS } \\
\text { and inferior + DS cells, } \\
\text { the ORS cells reformed a } \\
\text { long-shape hair follicle } \\
\text { structure that was seen } \\
\text { under microscope. }\end{array}$ & $\begin{array}{l}\text { 1-Dermal papilla } \\
\text { cells induced } \\
\text { superior and } \\
\text { inferior epithelial } \\
\text { cells to form hair } \\
\text { follicle on } \\
\text { nude mice. } \\
\text { 2-Low passage } \\
\text { dermal papilla } \\
\text { cells mixed with } \\
\text { hair follicle } \\
\text { epithelial cells } \\
\text { reformed many } \\
\text { typical hair } \\
\text { follicle structures } \\
\text { and produced } \\
\text { hair fibres after } \\
\text { transplantation } \\
\text { on nude mice. } \\
\text { 3-Dermal part of } \\
\text { hair follicle, such } \\
\text { as dermal papilla } \\
\text { cells and dermal } \\
\text { sheath cells, has } \\
\text { the ability to } \\
\text { induce hair } \\
\text { follicle formation } \\
\text { by interaction } \\
\text { with the } \\
\text { epithelial cells of } \\
\text { hair follicle. }\end{array}$ & [92] \\
\hline
\end{tabular}


Table 6. Cont.

\begin{tabular}{|c|c|c|c|c|c|}
\hline $\begin{array}{l}\text { Cell Types and } \\
\text { Scaffold }\end{array}$ & Type of Study & Experimental Design & Results & Conclusions & Reference \\
\hline $\begin{array}{l}\text { Human dermal } \\
\text { papilla (DP) } \\
\text { cells, hair } \\
\text { follicle } \\
\text { enriched } \\
\text { primary } \\
\text { cultures } \\
\text { (HFSCs) and } \\
\text { immortalized } \\
\text { human bulge } \\
\text { stem cell line } \\
\text { Tel-E6E7 and } \\
\text { dermal } \\
\text { fibroblasts (DF) } \\
\text { on acellular } \\
\text { dermal } \\
\text { matrices } \\
\text { Tissue } \\
\text { engineered skin }\end{array}$ & $\begin{array}{c}\text { In vitro and } \\
\text { in vivo study } \\
\text {-BALB/C nude } \\
\text { mice }\end{array}$ & $\begin{array}{l}\text {-DP cells and DF cells were } \\
\text { isolated from occipital human } \\
\text { scalp and HFSC cells were } \\
\text { isolated from human } \\
\text { skin biopsies. } \\
\text {-Immortalized human bulge } \\
\text { stem cell line Tel-E6E7 } \\
\text { was acquired. } \\
\text {-Porcine acellular dermal } \\
\text { matrices (ADMs), were seeded } \\
\text { with } 5 \times 10^{5} \mathrm{~cm}^{2} \text { DF or DP } \\
\text { cells as the dermal cellular } \\
\text { component. They were } \\
\text { cultured for } 7 \text { days. After that, } \\
\text { matrices were inverted and } \\
\text { seeded on the opposite side } \\
\text { with } 5 \times 10^{5} \text { cm }{ }^{2} \text { HFSCs or } \\
\text { Tel-E6E7 as the epidermal } \\
\text { cellular and cultured for } 21 \\
\text { days (combining liquid and } \\
\text { air-liquid phases). } \\
\text {-Tissue engineered skins were } \\
\text { grafted int the back of BALB/C } \\
\text { nude mice aged } 8 \text { weeks ( } n=6 \\
\text { per group): one type of } \\
\text { construct was seeded with } \\
\text { HFSCs and DPCs } \\
\text { (HFSC-DPC), a second type } \\
\text { was seeded with HFSCs and } \\
\text { DFs (HFSC-DF), and a third } \\
\text { type was seeded exclusively } \\
\text { with HFSCs without the } \\
\text { dermal component. } \\
\text {-Grafts were analysed at } 14,30 \\
\text { and } 70 \text { days. }\end{array}$ & $\begin{array}{l}\text { 1-Air-liquid interphase } \\
\text { improved in vitro skin } \\
\text { constructs: skin } \\
\text { constructs with HFSCs } \\
\text { alone or with DFs } \\
\text { (HFSC-DF) showed an } \\
\text { epidermis with a } \\
\text { proliferative basal layer, } \\
\text { incipient and irregular } \\
\text { stratum spinosum, } \\
\text { frequent dyskeratosis, } \\
\text { and a cornified layer. In } \\
\text { the HFSC-DPC skin } \\
\text { constructs, most regular } \\
\text { epidermis was observed. } \\
\text { 2-In vitro skin constructs } \\
\text { with DPCs showed a } \\
\text { higher number of } \\
\text { p63-Positive epidermal } \\
\text { basal cells and } \\
\text { epidermal invaginations. } \\
\text { 3-Presence of DPCs } \\
\text { favoured the graft-take } \\
\text { of composite skin and } \\
\text { improved the wound } \\
\text { healing process. } \\
\text { 4-After } 14 \text { days of } \\
\text { grafting, the HFSC-DPC } \\
\text { constructs showed the } \\
\text { highest number of blood } \\
\text { neo-vessels. Amount of } \\
\text { VEGF was six fold } \\
\text { higher than the amount } \\
\text { in the DF cultures } \\
\text { (927 } \pm 87 \text { pg/mL vs. } \\
\text { 147 } \pm 54 \text { pg/mL). } \\
\text { 5-Only the HFSC-DPC } \\
\text { constructs grafted in the } \\
\text { nude mice showed } \\
\text { notable epithelial } \\
\text { cyst-like inclusions in } \\
\text { the remodelling dermis } \\
\text { and expression of k6hf. }\end{array}$ & $\begin{array}{l}\text { 1-Presence of DP } \\
\text { cells in composite } \\
\text { skin constructs } \\
\text { generated in } \\
\text { air-liquid } \\
\text { interphase led to } \\
\text { the formation of } \\
\text { an epidermal-like } \\
\text { structure with } \\
\text { the most regular } \\
\text { stratification, } \\
\text { more } \\
\text { invaginations } \\
\text { that could } \\
\text { indicate hair } \\
\text { follicle } \\
\text { neogenesis } \\
\text { attempts, and } \\
\text { maintenance of } \\
\text { an epidermal } \\
\text { stem cell pool. }\end{array}$ & [93] \\
\hline
\end{tabular}


Table 6. Cont

\begin{tabular}{|c|c|c|c|c|c|}
\hline $\begin{array}{l}\text { Cell Types and } \\
\text { Scaffold }\end{array}$ & Type of Study & Experimental Design & Results & Conclusions & Reference \\
\hline $\begin{array}{c}\text { Human } \\
\text { keratinocytes, } \\
\text { fibroblasts, } \\
\text { dermal papilla } \\
\text { cells and } \\
\text { GFP-tagged } \\
\text { HUVECs. } \\
\text { Human skin } \\
\text { constructs } \\
\text { (HSCs) in type I } \\
\text { collagen gel. }\end{array}$ & $\begin{array}{l}\text { In vitro and } \\
\text { in vivo study } \\
\text {-Male } \\
\text { immunodeficient } \\
\text { nude mice } \\
\text { (athymic nude, } \\
\text { Crl:NU(NCr)- } \\
\text { Foxn1nu }\end{array}$ & 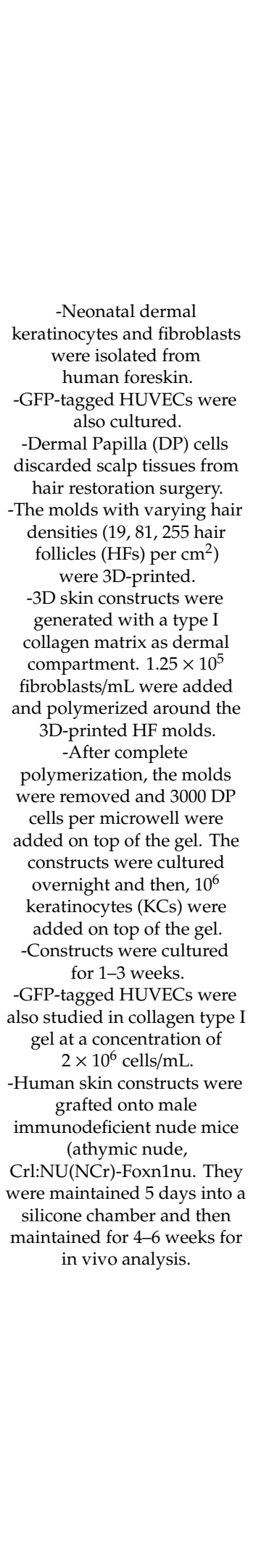 & 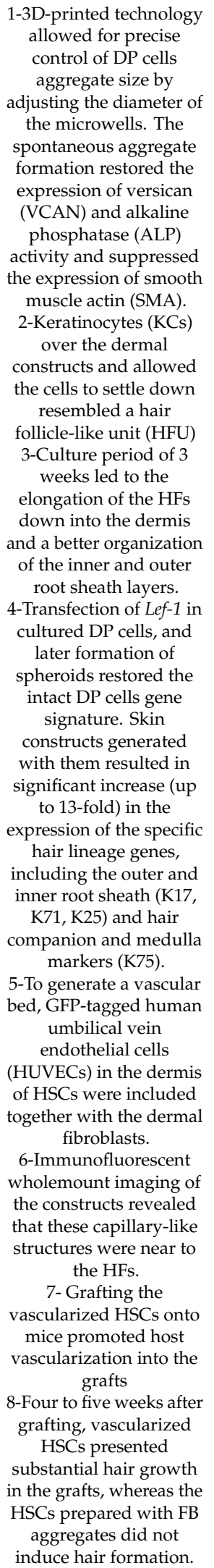 & $\begin{array}{l}\text { 1-This tissue } \\
\text { engineering } \\
\text { exploits the } \\
\text { epidermal- } \\
\text { mesenchymal } \\
\text { interactions } \\
\text { during hair } \\
\text { development } \\
\text { while } \\
\text { synthetically } \\
\text { guiding the } \\
\text { physiological } \\
\text { conformation } \\
\text { and } \\
\text { reconstituting the } \\
\text { gene signature of } \\
\text { cultured cells to } \\
\text { induce human } \\
\text { hair growth } \\
\text { in vitro and in } \\
\text { mice. }\end{array}$ & [94] \\
\hline
\end{tabular}


Moreover, Chermnykh et al. showed that human keratinocytes from outer root sheath and dermal papillae cells cultured in a 3D network of extracellular matrix proteins and collagen formed tubule-like structures in this skin-equivalent in vitro [81], but did not form complete hair follicles. Similarly, Sriwiriyanont et al. observed neofollicle formation in nude mice grafted with engineered skin substitutes containing murine dermal papillae cells and human keratinocytes in a collagen-glycosaminoglycan matrix, but not in those containing human dermal papillae cells and human keratinocytes [83].

Ehama et al. showed the formation of hair follicle-like structures using human primary cultures of foreskin- or adult-derived epidermal cells co-grafted with murine dermal papillae cells by a chamber assay. The innermost regions were similar to the hair cortex and medulla of mature human follicles but they did not show a bulge region, all the follicular epithelial layers, and versican was not expressed, suggesting that the differentiation process was altered [84]. At the same time, Kang et al. obtained spheroid microtissues by culturing human dermal papillae cells in a 96-well low-binding plate, and implanted them intradermically into nude mice using the "patch assay", generating new hair follicles. However, these hair follicles were not observed when monolayer dermal papillae cell cultures were used, concluding that cultured human dermal papillae cells do not induce hair neogenesis unless changes in the culture conditions were made [85]. Later, Higgins et al. found that human hair follicle dermal cells can be interchanged with interfollicular fibroblasts and used as an alternative cell source for establishing the dermal component of engineered skin, both in vitro and in vivo. These authors established some in vitro skin constructs by incorporating into the collagenous dermal compartment: primary interfollicular dermal fibroblasts, hair follicle dermal papilla cells, or hair follicle dermal sheath cells. In vivo skins were established by mixing dermal cells and keratinocytes in chambers on top of immunologically compromised mice. They found that all fibroblast subtypes were capable of supporting the growth of overlying epithelial cells, both in vitro and in vivo, being hair follicle dermal sheath cells superior to fibroblasts in their capacity to influence the establishment of a basal lamina. They also evaluated the human dermal papilla cells' transcriptome, observing that monolayer dermal papillae cells cultures showed the most important changes immediately after early outgrowths from dermal papillae explants, which suggests that human dermal papillae cells spheroids were able to initiate hair follicle morphogenesis, but the production of a complete hair follicle required additional signals $[90,91]$. Others investigators produced dermal papillae cell spheroids from cultured dermal papillae cells on a Matrigel ${ }^{\mathrm{TM}}$ (Corning Life Sciences, Corning, NY, USA) scaffold, in order to restore dermal papillae signature gene expression of NCAM, versican, and $\alpha$-smooth muscle actin, markers that are lost during the monolayer culture. They also observed that these dermal papillae cell-spheres, combined with hair germinal matrix cells onto Matrigel-coated plates, produced colorless fiber-like structures in vitro [82].

Other groups have cultured dermal mesenchymal cells in 3D conditions as the organotypic method of culturing cells inside a scaffold. This gel was seeded with keratinocytes from interfollicular skin, superior outer root sheath, or inferior outer root sheath obtaining an in vitro bi-layered skin. Nevertheless, only the constructs containing superior outer root sheath keratinocytes showed hair follicle-like structures [92]. Thangapazham et al. used a dermal equivalent composed of dermal papillae cells from human scalp contained in a collagen-I gel. Eight weeks after grafting onto nude mice, these constructs presented hair follicles showing bulb, dermal sheath, hair matrix, and cortex. Histological analysis showed concentric layers of inner root sheath and outer root sheath, sebaceous glands, and hair shaft. Immunohistochemistry assays revealed that both epithelial and dermal cells from neofollicles were of human origin, and dermal papillae cells and dermal sheath cells expressed human nestin and versican [86]. Leirós et al. showed that both epithelial and dermal cultured cells from adult human scalp in a dermal scaffold were able to produce in vivo structures that recapitulate embryonic hair development. In fourteen days, histological structures reminiscent of many different stages of embryonic hair follicle development were observed in the grafted area. These structures showed concentric cellular layers of human origin, and expressed K6hf, a keratin present in epithelial cells of the companion layer. However, the presence of fully mature hair follicles was not observed [93]. 
Recently, Abaci et al. regenerated for the first time a truly functional human skin in an entirely ex vivo context that incorporated hair follicles from cultured human cells. They used a biomimetic approach for generation of human hair follicles within human skin constructs by recapitulating the physiological 3D organization of cells in the hair follicle microenvironment using 3D-printed molds. Overexpression of Lef-1 in dermal papilla cells restored the intact dermal papilla cells' transcriptional signature and enhanced the efficiency of hair follicle differentiation in human skin constructs. After that, vascularization of hair follicle-bearing human skin constructs increased graft survival and enabled efficient human hair growth in mice. They were able to generate 225 hair follicles, starting from only one hair follicles donor tissue, which was not possible with previous techniques [94].

Some clinical trials with tissue engineered therapies for alopecia have been developed in recent years. A Taiwanese group designed an observational study with 400 healthy adults that were going to receive cosmetic surgery such as removal of moles. The aim of this study was to note if a sample of in vitro cultured dermal papilla cells was able to induce hair follicle formation after maintaining their spherical structure before transplanting into dermis in vivo. To date, the authors have not published the results of this study [95].

\section{Conclusions}

Alopecia areata and androgenic alopecia are still challenging conditions for dermatologists, with a lack of highly effect treatments. With this background, advanced therapies are a promising therapeutic option that have shown good results in preclinical studies. However, more clinical studies are needed to verify if ATMPs can be a safe and effective treatment for diverse forms of non-scarring alopecia.

Author Contributions: Conceptualization: A.M.-L. (Antonio Martinez-Lopez), A.M.-L. (Alejandro Molina-Leyva), S.A.-S.; methodology: A.M.-L. (Antonio Martinez-Lopez), S.A.-S.; investigation of published papers: A.M.-L. (Antonio Martinez-Lopez), T.M.-V., Á.S.-S.; writing-original draft preparation: A.M.-L. (Antonio Martinez-Lopez), T.M.-V., Á.S.-S.; writing-review and editing: A.M.-L. (Alejandro Molina-Leyva), S.A.-S.; supervision: A.M.-L. (Alejandro Molina-Leyva), S.A.-S. All authors have read and agreed to the published version of the manuscript.

Funding: We gratefully acknowledge financial support from Instituto de Salud Carlos III through the projects PI-17/02083 (co-funded by European Regional Development Fund "A way to make Europe") and Ministry of Health of the Andalusian Regional Government (SAS PI-0458-2016 and AML PIGE-0249-2019).

Conflicts of Interest: The authors declare no conflict of interest.

\section{References}

1. Gonzalez-Cantero, A.; Arias-Santiago, S.; Buendía-Eisman, A.; Molina-Leyva, A.; Gilaberte, Y.; Fernández-Crehuet, P.; Husein-ElAhmed, H.; Viera-Ramírez, A.; Fernández-Peñas, P.; Taberner, R.; et al. Do Dermatologic Diagnosis Change in Hot vs Cold Periods of The Year? A Sub-Analysis of the DIADERM National Sample (Spain 2016). Actas Dermo-Sifiliográficas 2019, 110, 734-743. [CrossRef]

2. Okhovat, J.-P.; Marks, D.H.; Manatis-Lornell, A.; Hagigeorges, D.; Locascio, J.J.; Senna, M.M. Association Between Alopecia Areata, Anxiety, and Depression: A Systematic Review and Meta-analysis. J. Am. Acad. Dermatol. 2019. [CrossRef]

3. Almohanna, H.M.; Perper, M.; Tosti, A. Safety concerns when using novel medications to treat alopecia. Expert Opin. Drug Saf. 2018, 17, 1115-1128. [CrossRef]

4. Rongioletti, F.; Christana, K. Cicatricial (Scarring) Alopecias: An overview of pathogenesis, classification, diagnosis, and treatment. Am. J. Clin. Dermatol. 2012, 13, 247-260. [CrossRef] [PubMed]

5. Strong, A.L.; Neumeister, M.W.; Levi, B. Stem Cells and Tissue Engineering: Regeneration of the Skin and Its Contents. Clin. Plast. Surg. 2017, 44, 635-650. [CrossRef]

6. Campos-Muñoz, A. Advanced therapies in current Medicine. Actual. Med. 2017, 102, 133. [CrossRef]

7. Erben, R.G.; Lima, B.S.; Reischl, I.; Steinhoff, G.; Tiedemann, G.; Dalemans, W.; Vos, A.; Janssen, R.T.; Le Blanc, K.; Van Osch, G.J.; et al. White paper on how to go forward with cell-based advanced therapies in Europe. Tissue Eng. Part A 2014, 20, 2549-2554. [CrossRef] 
8. Regulation (EC) No 1394/2007 of the European Parliament and of the Council of 13 November 2007 on Advanced Therapy Medicinal Products and Amending Directive 2001/83/EC and Regulation (EC) No 726/2004. Available online: https://ec.europa.eu/health//sites/health/files/files/eudralex/vol-1/reg_2007_1394/ reg_2007_1394_en.pdf (accessed on 22 December 2019).

9. Cuende, N.; Álvarez-Márquez, A.J.; Díaz-Aunión, C.; Castro, P.; Huet, J.; Pérez-Villares, J.M. The regenerative medicine and stem cell business: Confusion with legal implications. Gac. Sanit. 2020. [CrossRef]

10. EudraLex. The Rules Governing Medicinal Products in the European Union Volume 4. Guidelines on Good Manufacturing Practice Specific to Advanced Therapy Medicinal Products. Available online: https://ec.europa. eu/health/sites/health/files/files/eudralex/vol-4/2017_11_22_guidelines_gmp_for_atmps.pdf (accessed on 22 December 2019).

11. Thirabanjasak, D.; Tantiwongse, K.; Thorner, P.S. Angiomyeloproliferative lesions following autologous stem cell therapy. J. Am. Soc. Nephrol. 2010, 21, 1218-1222. [CrossRef] [PubMed]

12. Moll, G.; Drzeniek, N.; Kamhieh-Milz, J.; Geissler, S.; Volk, H.-D.; Reinke, P. MSC Therapies for COVID-19: Importance of Patient Coagulopathy, Thromboprophylaxis, Cell Product Quality and Mode of Delivery for Treatment Safety and Efficacy. Front. Immunol. 2020, 11, 1091. [CrossRef]

13. Wang, L.; Ji, H.; Zhou, J.; Xie, J.; Zhong, Z.; Li, M.; Bai, W.; Li, N.; Zhang, Z.; Wang, X.; et al. Therapeutic Potential of Umbilical Cord Mesenchymal Stromal Cells Transplantation for Cerebral Palsy: A Case Report. Case Rep. Transplant. 2013, 2013, 146347. [CrossRef]

14. Maxson, S.; Lopez, E.A.; Yoo, D.; Danilkovitch-Miagkova, A.; Leroux, M.A. Concise Review: Role of Mesenchymal Stem Cells in Wound Repair. STEM CELLS Transl. Med. 2012, 1, 142-149. [CrossRef] [PubMed]

15. Kim, S.; Lee, S.K.; Kim, H.; Kim, T.M. Exosomes Secreted from Induced Pluripotent Stem Cell-Derived Mesenchymal Stem Cells Accelerate Skin Cell Proliferation. Int. J. Mol. Sci. 2018, 19, 3119. [CrossRef]

16. Yates, C.C.; Rodrigues, M.; Nuschke, A.; Johnson, Z.I.; Whaley, D.; Stolz, D.; Newsome, J.; Wells, A. Multipotent stromal cells/mesenchymal stem cells and fibroblasts combine to minimize skin hypertrophic scarring. Stem Cell Res. Ther. 2017, 8, 193. [CrossRef]

17. Almalki, S.G.; Agrawal, D.K. Key transcription factors in the differentiation of mesenchymal stem cells. Differentiation 2016, 92, 41-51. [CrossRef]

18. Park, J.S.; Yang, H.N.; Woo, D.G.; Jeon, S.Y.; Park, K.-H. The promotion of chondrogenesis, osteogenesis, and adipogenesis of human mesenchymal stem cells by multiple growth factors incorporated into nanosphere-coated microspheres. Biomaterials 2011, 32, 28-38. [CrossRef] [PubMed]

19. Miyagawa, I.; Nakayamada, S.; Kondo, M.; Tanaka, Y. Regulatory Mechanism of The Induction of Regulatory T Cells through Growth Factors Released by Human Mesenchymal Stem Cells. Crit. Rev. Immunol. 2018, 38, 471-478. [CrossRef]

20. Debnath, T.; Chelluri, L.K. Standardization and quality assessment for clinical grade mesenchymal stem cells from human adipose tissue. Hematol. Transfus. Cell Ther. 2019, 41, 7-16. [CrossRef] [PubMed]

21. Silva, J.D.; Lopes-Pacheco, M.; Paz, A.H.R.; Cruz, F.F.; Melo, E.B.; De Oliveira, M.V.; Xisto, D.G.; Capelozzi, V.L.; Morales, M.M.; Pelosi, P.; et al. Mesenchymal Stem Cells from Bone Marrow, Adipose Tissue, and Lung Tissue Differentially Mitigate Lung and Distal Organ Damage in Experimental Acute Respiratory Distress Syndrome. Crit. Care Med. 2018, 46, e132-e140. [CrossRef]

22. Zare, H.; Jamshidi, S.; Dehghan, M.M.; Saheli, M.; Piryaei, A. Bone marrow or adipose tissue mesenchymal stem cells: Comparison of the therapeutic potentials in mice model of acute liver failure. J. Cell. Biochem. 2018, 119, 5834-5842. [CrossRef] [PubMed]

23. Sinclair, K.L.; Mafi, P.; Mafi, R.; Khan, W.S. The Use of Growth Factors and Mesenchymal Stem Cells in Orthopaedics: In particular, their use in Fractures and Non-Unions: A Systematic Review. Curr. Stem Cell Res. Ther. 2017, 12, 312-325. [CrossRef]

24. Liu, X.; Li, Q.; Niu, X.; Hu, B.; Chen, S.; Song, W.; Ding, J.; Zhang, C.; Wang, Y. Exosomes Secreted from Human-Induced Pluripotent Stem Cell-Derived Mesenchymal Stem Cells Prevent Osteonecrosis of the Femoral Head by Promoting Angiogenesis. Int. J. Biol. Sci. 2017, 13, 232-244. [CrossRef]

25. Damia, E.; Chicharro, D.; Lopez, S.; Cuervo, B.; Rubio, M.; Sopena, J.; Vilar, J.M.; Carrillo, J.M. Adipose-Derived Mesenchymal Stem Cells: Are They a Good Therapeutic Strategy for Osteoarthritis? Int. J. Mol. Sci. 2018, 19, 1926. [CrossRef] [PubMed] 
26. Westhauser, F.; Senger, A.-S.; Reible, B.; Moghaddam, A. In Vivo Models for the Evaluation of the Osteogenic Potency of Bone Substitutes Seeded with Mesenchymal Stem Cells of Human Origin: A Concise Review. Tissue Eng. Part C Methods 2017, 23, 881-888. [CrossRef]

27. Kim, K.H.; Blasco-Morente, G.; Cuende, N.; Arias-Santiago, S. Mesenchymal stromal cells: Properties and role in management of cutaneous diseases. J. Eur. Acad. Dermatol. Venereol. 2017, 31, 414-423. [CrossRef] [PubMed]

28. Sellheyer, K.; Krahl, D. Skin mesenchymal stem cells: Prospects for clinical dermatology. J. Am. Acad. Dermatol. 2010, 63, 859-865. [CrossRef]

29. Maranda, E.L.; Rodriguez-Menocal, L.; Badiavas, E.V. Role of Mesenchymal Stem Cells in Dermal Repair in Burns and Diabetic Wounds. Curr. Stem Cell Res. Ther. 2016, 12, 61-70. [CrossRef]

30. Marfia, G.; Navone, S.E.; Di Vito, C.; Ughi, N.; Tabano, S.; Miozzo, M.; Tremolada, C.; Bolla, G.; Crotti, C.; Ingegnoli, F.; et al. Mesenchymal stem cells: Potential for therapy and treatment of chronic non-healing skin wounds. Organogenesis 2015, 11, 183-206. [CrossRef] [PubMed]

31. Liu, Z.; Yu, D.; Xu, J.; Li, X.; Wang, X.; He, Z.; Zhao, T. Human umbilical cord mesenchymal stem cells improve irradiation-induced skin ulcers healing of rat models. Biomed. Pharmacother. 2018, 101, 729-736. [CrossRef]

32. Zhang, P.; Kling, R.E.; Ravuri, S.K.; Kokai, L.E.; Rubin, J.P.; Chai, J.-K.; Marra, K.G. A review of adipocyte lineage cells and dermal papilla cells in hair follicle regeneration. J. Tissue Eng. 2014, 5. [CrossRef]

33. Owczarczyk-Saczonek, A.; Krajewska-Włodarczyk, M.; Kruszewska, A.; Banasiak, Ł.; Placek, W.; Maksymowicz, W.; Wojtkiewicz, J. Therapeutic Potential of Stem Cells in Follicle Regeneration. Stem Cells Int. 2018, 2018, 1049641. [CrossRef]

34. Gentile, P.; Scioli, M.G.; Bielli, A.; Orlandi, A.; Cervelli, V. Stem cells from human hair follicles: First mechanical isolation for immediate autologous clinical use in androgenetic alopecia and hair loss. Stem Cell Investig. 2017, 4, 58. [CrossRef]

35. Byun, J.W.; Kim, H.J.; Na, K.; Ko, H.S.; Song, H.J.; Song, S.U.; Jeon, M.-S.; Choi, G.S. Bone marrow-derived mesenchymal stem cells prevent alopecia areata development through the inhibition of NKG2D expression: A pilot study. Exp. Dermatol. 2017, 26, 532-535. [CrossRef]

36. Gilhar, A.; Etzioni, A.; Paus, R. Alopecia Areata. N. Engl. J. Med. 2012, 366, 1515-1525. [CrossRef]

37. McPhee, C.G.; Duncan, F.J.; Silva, K.A.; King, L.E.; HogenEsch, H.; Roopenian, D.C.; Everts, H.B.; Sundberg, J.P. Increased Expression of Cxcr3 and Its Ligands, Cxc19 and Cxcl10, during the Development of Alopecia Areata in the Mouse. J. Investig. Dermatol. 2012, 132, 1736-1738. [CrossRef]

38. Garza, L.A.; Yang, C.-C.; Zhao, T.; Blatt, H.B.; Lee, M.; He, H.; Stanton, D.C.; Carrasco, L.; Spiegel, J.H.; Tobias, J.W.; et al. Bald scalp in men with androgenetic alopecia retains hair follicle stem cells but lacks CD200-rich and CD34-positive hair follicle progenitor cells. J. Clin. Investig. 2011, 121, 613-622. [CrossRef]

39. Kang, J.-S.; Zheng, Z.; Choi, M.J.; Lee, S.-H.; Kim, D.-Y.; Cho, S.B. The effect of CD34+ cell-containing autologous platelet-rich plasma injection on pattern hair loss: A preliminary study. J. Eur. Acad. Dermatol. Venereol. 2012, 28, 72-79. [CrossRef]

40. Ma, X.; Chen, S.; Jin, W.; Gao, Y. Th1/Th2 PB balance and CD200 expression of patients with active severe alopecia areata. Exp. Ther. Med. 2017, 13, 2883-2887. [CrossRef]

41. Yoshida, R.; Tanaka, K.; Amagai, M.; Ohyama, M. Involvement of the bulge region with decreased expression of hair follicle stem cell markers in senile female cases of alopecia areata. J. Eur. Acad. Dermatol. Venereol. 2010, 25, 1346-1350. [CrossRef]

42. Leirós, G.J.; Attorresi, A.I.; Balañá, M.E. Hair follicle stem cell differentiation is inhibited through cross-talk between $\mathrm{Wnt} / \beta$-catenin and androgen signalling in dermal papilla cells from patients with androgenetic alopecia. Br. J. Dermatol. 2012, 166, 1035-1042. [CrossRef]

43. Kim, J.E.; Oh, J.H.; Woo, Y.J.; Jung, J.H.; Jeong, K.H.; Kang, H. Effects of mesenchymal stem cell therapy on alopecia areata in cellular and hair follicle organ culture models. Exp. Dermatol. 2018, 29, 265-272. [CrossRef]

44. Bak, D.H.; Choi, M.J.; Kim, S.R.; Lee, B.C.; Kim, J.M.; Jeon, E.S.; Oh, W.; Lim, E.S.; Park, B.C.; Kim, M.J.; et al. Human umbilical cord blood mesenchymal stem cells engineered to overexpress growth factors accelerate outcomes in hair growth. Korean J. Physiol. Pharmacol. 2018, 22, 555-566. [CrossRef] [PubMed]

45. Fawzy, M.M.; Gabrb, H.M.; Maadawy, Z.M.E. Autologous progenitor cell implantation as a novel therapeutic intervention for alopecia areata. J. Egypt Women Dermatol. Soc. 2011, 8, 11-16. [CrossRef] 
46. Elmaadawi, I.H.; Mohamed, B.M.; Ibrahim, Z.A.S.; Abdou, S.H.; El Attar, Y.A.; Youssef, A.; Shamloula, M.M.; Taha, A.; Metwally, H.G.; El Afandy, M.M.; et al. Stem cell therapy as a novel therapeutic intervention for resistant cases of alopecia areata and androgenetic alopecia. J. Dermatol. Treat. 2018, 29, 431-440. [CrossRef]

47. Li, Y.; Yan, B.; Wang, H.; Li, H.; Li, Q.; Zhao, D.; Chen, Y.; Zhang, Y.; Li, W.; Zhang, J.; et al. Hair regrowth in alopecia areata patients following Stem Cell Educator therapy. BMC Med. 2015, 13, 87. [CrossRef] [PubMed]

48. Perez-Meza, D.; Ziering, C.; Sforza, M.; Krishnan, G.; Ball, E.; Daniels, E. Hair follicle growth by stromal vascular fraction-enhanced adipose transplantation in baldness. Stem Cells Cloning Adv. Appl. 2017, $10,1$. [CrossRef]

49. Anderi, R.; Makdissy, N.; Azar, A.; Rizk, F.; Hamade, A. Cellular therapy with human autologous adipose-derived adult cells of stromal vascular fraction for alopecia areata. Stem Cell Res. Ther. 2018, 9, 141. [CrossRef]

50. Nilforoushzadeh, M.A.; Lotfi, E.; Heidari-Kharaji, M. Autologous adipose transplantation an effective method to treat alopecia after trauma: A case report. Clin. Cosmet. Investig. Dermatol. 2019, 12, 647-651. [CrossRef]

51. Ruiz, R.G.; Rosell, J.M.C.; Ceccarelli, G.; De Sio, C.; De Angelis, G.C.; Pinto, H.; Astarita, C.; Graziano, A. Progenitor-cell-enriched micrografts as a novel option for the management of androgenetic alopecia. J. Cell. Physiol. 2019, 235, 4587-4593. [CrossRef]

52. A Study to Evaluate and Compare Injections of Autologous Dermal and Epidermal Cells into the Balding Scalp of Subjects with Hair Loss (CA-0002899). ClinicalTrials.Gov. Available online: https://clinicaltrials.gov/ ct2/show/NCT01451112 (accessed on 22 December 2019).

53. Autologous Adipose-Derived Adult Stromal Vascular Cell Transplantation for Alopecia. ClinicalTrials.gov. Available online: https://clinicaltrials.gov/ct2/show/NCT03427905 (accessed on 22 December 2019).

54. AGA Biocellular Stem/Stromal Hair Regenerative Study. ClinicalTrials.gov. Available online: https: //clinicaltrials.gov/ct2/show/NCT02849470 (accessed on 22 December 2019).

55. Biocellular-Cellular Regenerative Treatment Scaring Alopecia and Alopecia Areata. ClinicalTrials.gov. Available online: https:/clinicaltrials.gov/ct2/show/NCT03078686 (accessed on 22 December 2019).

56. Nanofat Grafting for Treatment of Androgenetic Alopecia. ClinicalTrials.gov. Available online: https: //clinicaltrials.gov/ct2/show/NCT03506503 (accessed on 22 December 2019).

57. Kay, M.A. State-of-the-art gene-based therapies: The road ahead. Nat. Rev. Genet. 2011, 12, 316-328. [CrossRef]

58. Williams, R.S.; Johnston, S.A.; Riedy, M.; DeVit, M.J.; McElligott, S.G.; Sanford, J.C. Introduction of foreign genes into tissues of living mice by DNA-coated microprojectiles. Proc. Natl. Acad. Sci. USA 1991, 88, 2726-2730. [CrossRef]

59. Gorell, E.; Nguyen, N.; Lane, A.; Siprashvili, Z. Gene Therapy for Skin Diseases. Cold Spring Harb. Perspect. Med. 2014, 4, a015149. [CrossRef] [PubMed]

60. Rosa, J.; Suzuki, I.; Kravicz, M.; Caron, A.; Pupo, A.V.; Praça, F.G.; Bentley, M.V.L.B. Current Non-viral siRNA Delivery Systems as a Promising Treatment of Skin Diseases. Curr. Pharm. Des. 2018, 24, 2644-2663. [CrossRef]

61. Hannon, G.J.; Rossi, J.J. Unlocking the potential of the human genome with RNA interference. Nat. Cell Biol. 2004, 431, 371-378. [CrossRef]

62. Ruan, R.; Chen, M.; Sun, S.; Wei, P.; Zou, L.; Liu, J.; Gao, D.; Wen, L.; Ding, W. Topical and Targeted Delivery of siRNAs to Melanoma Cells Using a Fusion Peptide Carrier. Sci. Rep. 2016, 6, 29159. [CrossRef]

63. Baroli, B. Penetration of nanoparticles and nanomaterials in the skin: Fiction or reality? J. Pharm. Sci. 2010, 99, 21-50. [CrossRef]

64. Lenn, J.D.; Neil, J.; Donahue, C.; Demock, K.; Tibbetts, C.V.; Cote-Sierra, J.; Smith, S.H.; Rubenstein, D.; Therrien, J.-P.; Pendergrast, P.S.; et al. RNA Aptamer Delivery through Intact Human Skin. J. Investig. Dermatol. 2018, 138, 282-290. [CrossRef]

65. Singhal, M.; Lapteva, M.; Kalia, Y.N. Formulation challenges for 21st century topical and transdermal delivery systems. Expert Opin. Drug Deliv. 2017, 14, 705-708. [CrossRef]

66. Kushibiki, T.; Matsumoto, K.; Nakamura, T.; Tabata, Y. Suppression of tumor metastasis by NK4 plasmid DNA released from cationized gelatin. Gene Ther. 2004, 11, 1205-1214. [CrossRef] [PubMed]

67. Biswas, S.; Torchilin, V.P. Dendrimers for siRNA Delivery. Pharmaceuticals 2013, 6, 161-183. [CrossRef] 
68. Haigh, O.; Depelsenaire, A.C.; Meliga, S.C.; Yukiko, S.R.; McMillan, N.A.; Frazer, I.H.; Kendall, M.A. CXCL1 gene silencing in skin using liposome-encapsulated siRNA delivered by microprojection array. J. Control. Release 2014, 194, 148-156. [CrossRef]

69. Gilleron, J.; Querbes, W.; Zeigerer, A.; Borodovsky, A.; Marsico, G.; Schubert, U.; Manygoats, K.; Seifert, S.; Andree, C.; Stöter, M.; et al. Image-based analysis of lipid nanoparticle-mediated siRNA delivery, intracellular trafficking and endosomal escape. Nat. Biotechnol. 2013, 31, 638-646. [CrossRef]

70. Chakraborty, C.; Sharma, A.R.; Sharma, G.; Doss, C.G.P.; Lee, S.-S. Therapeutic miRNA and siRNA: Moving from Bench to Clinic as Next Generation Medicine. Mol. Ther. Nucleic Acids 2017, 8, 132-143. [CrossRef]

71. Nakamura, M.; Jo, J.-I.; Tabata, Y.; Ishikawa, O. Controlled Delivery of T-box21 Small Interfering RNA Ameliorates Autoimmune Alopecia (Alopecia Areata) in a C3H/HeJ Mouse Model. Am. J. Pathol. 2008, 172, 650-658. [CrossRef]

72. Goodarzi, H.; Abbasi, A.; Saffari, M.; Haghighi, M.F.; Tabei, S.M.B.; Daloii, M.N. Differential expression analysis of balding and nonbalding dermal papilla microRNAs in male pattern baldness with a microRNA amplification profiling method. Br. J. Dermatol. 2012, 166, 1010-1016. [CrossRef]

73. Sierra-Sánchez, Á.; Fernández-González, A.; Lizana-Moreno, A.; Espinosa-Ibáñez, O.; Martinez-Lopez, A.; Guerrero-Calvo, J.; Fernández-Porcel, N.; Ruiz-García, A.; Ordóñez-Luque, A.; Carriel, V.; et al. Hyaluronic acid biomaterial for human tissue-engineered skin substitutes: Preclinical comparative in vivo study of wound healing. J. Eur. Acad. Dermatol. Venereol. 2020, 34, 2414-2427. [CrossRef]

74. Papini, R. Management of burn injuries of various depths. BMJ 2004, 329, 158-160. [CrossRef]

75. Shevchenko, R.V.; James, S.E. A review of tissue-engineered skin bioconstructs available for skin reconstruction. J. R. Soc. Interface 2009, 7, 229-258. [CrossRef]

76. Lee, L.F.; Jiang, T.X.; Garner, W.; Chuong, C.-M. A Simplified Procedure to Reconstitute Hair-Producing Skin. Tissue Eng. Part C Methods 2011, 17, 391-400. [CrossRef]

77. Nakao, K.; Morita, R.; Saji, Y.; Ishida, K.; Tomita, Y.; Ogawa, M.; Saitoh, M.; Tomooka, Y.; Tsuji, T. The development of a bioengineered organ germ method. Nat. Methods 2007, 4, 227-230. [CrossRef]

78. Asakawa, K.; Toyoshima, K.-E.; Ishibashi, N.; Tobe, H.; Iwadate, A.; Kanayama, T.; Hasegawa, T.; Nakao, K.; Toki, H.; Noguchi, S.; et al. Hair organ regeneration via the bioengineered hair follicular unit transplantation. Sci. Rep. 2012, 2, 424. [CrossRef]

79. Toyoshima, K.E.; Asakawa, K.; Ishibashi, N.; Toki, H.; Ogawa, M.; Hasegawa, T.; Irié, T.; Tachikawa, T.; Sato, A.J.; Takeda, A.; et al. Fully functional hair follicle regeneration through the rearrangement of stem cells and their niches. Nat. Commun. 2012, 3, 784. [CrossRef]

80. Qiao, J.; Turetsky, A.; Kemp, P.; Teumer, J. Hair morphogenesis in vitro: Formation of hair structures suitable for implantation. Regen. Med. 2008, 3, 683-692. [CrossRef]

81. Chermnykh, E.S.; Vorotelyak, E.A.; Gnedeva, K.Y.; Moldaver, M.V.; Yegorov, Y.E.; Vasiliev, A.V.; Terskikh, V.V. Dermal papilla cells induce keratinocyte tubulogenesis in culture. Histochem. Cell Biol. 2010, 133, 567-576. [CrossRef]

82. Miao, Y.; Bin Sun, Y.; Liu, B.C.; Jiang, J.D.; Hu, Z.Q. Controllable Production of Transplantable Adult Human High-Passage Dermal Papilla Spheroids Using 3D Matrigel Culture. Tissue Eng. Part A 2014, 20, 2329-2338. [CrossRef] [PubMed]

83. Sriwiriyanont, P.; Lynch, K.A.; Maier, E.A.; Hahn, J.M.; Supp, D.M.; Boyce, S.T. Morphogenesis of chimeric hair follicles in engineered skin substitutes with human keratinocytes and murine dermal papilla cells. Exp. Dermatol. 2012, 21, 783-785. [CrossRef]

84. Ehama, R.; Ishimatsu-Tsuji, Y.; Iriyama, S.; Ideta, R.; Soma, T.; Yano, K.; Kawasaki, C.; Suzuki, S.; Shirakata, Y.; Hashimoto, K.; et al. Hair Follicle Regeneration Using Grafted Rodent and Human Cells. J. Investig. Dermatol. 2007, 127, 2106-2115. [CrossRef] [PubMed]

85. Kang, B.M.; Kwack, M.H.; Kim, M.K.; Kim, J.C.; Sung, Y.K. Sphere Formation Increases the Ability of Cultured Human Dermal Papilla Cells to Induce Hair Follicles from Mouse Epidermal Cells in a Reconstitution Assay. J. Investig. Dermatol. 2012, 132, 237-239. [CrossRef]

86. Thangapazham, R.L.; Klover, P.; Wang, J.-A.; Zheng, Y.; Devine, A.; Li, S.; Sperling, L.; Cotsarelis, G.; Darling, T.N. Dissociated human dermal papilla cells induce hair follicle neogenesis in grafted dermal-epidermal composites. J. Investig. Dermatol. 2013, 134, 538-540. [CrossRef] 
87. Osada, A.; Iwabuchi, T.; Kishimoto, J.; Hamazaki, T.S.; Okochi, H. Long-Term Culture of Mouse Vibrissal Dermal Papilla Cells and De Novo Hair Follicle Induction. Tissue Eng. 2007, 13, 975-982. [CrossRef] [PubMed]

88. Young, T.-H.; Lee, C.-Y.; Chiu, H.-C.; Hsu, C.-J.; Lin, S.-J. Self-assembly of dermal papilla cells into inductive spheroidal microtissues on poly (ethylene-co-vinyl alcohol) membranes for hair follicle regeneration. Biomaterials 2008, 29, 3521-3530. [CrossRef]

89. Soma, T.; Fujiwara, S.; Shirakata, Y.; Hashimoto, K.; Kishimoto, J. Hair?inducing ability of human dermal papilla cells cultured under Wnt/??-catenin signalling activation. Exp. Dermatol. 2012, 21,307-309. [CrossRef]

90. Higgins, C.A.; Chen, J.C.; Cerise, J.E.; Jahoda, C.A.B.; Christiano, A.M. Microenvironmental reprogramming by three-dimensional culture enables dermal papilla cells to induce de novo human hair-follicle growth. Proc. Natl. Acad. Sci. USA 2013, 110, 19679-19688. [CrossRef] [PubMed]

91. Higgins, C.A.; Roger, M.F.; Hill, R.P.; Ali-Khan, A.S.; Garlick, J.A.; Christiano, A.M.; Jahoda, C.A. Multifaceted role of hair follicle dermal cells in bioengineered skins. Br. J. Dermatol. 2017, 176, 1259-1269. [CrossRef]

92. Wu, J.J.; Zhu, T.-Y.; Lu, Y.-G.; Liu, R.-Q.; Mai, Y.; Cheng, B.; Lu, Z.-F.; Zhong, B.-Y.; Tang, S.-Q. Hair follicle reformation induced by dermal papilla cells from human scalp skin. Arch. Dermatol. Res. 2006, 298, 183-190. [CrossRef] [PubMed]

93. Leirós, G.J.; Kusinsky, A.G.; Drago, H.; Bossi, S.; Sturla, F.; Castellanos, M.L.; Stella, I.Y.; Balañá, M.E. Dermal Papilla Cells Improve the Wound Healing Process and Generate Hair Bud-Like Structures in Grafted Skin Substitutes Using Hair Follicle Stem Cells. STEM CELLS Transl. Med. 2014, 3, 1209-1219. [CrossRef]

94. Abaci, H.E.; Coffman, A.; Doucet, Y.; Chen, J.; Jacków, J.; Wang, E.; Guo, Z.; Shin, J.U.; Jahoda, C.A.; Christiano, A.M. Tissue engineering of human hair follicles using a biomimetic developmental approach. Nat. Commun. 2018, 9, 1-11. [CrossRef]

95. Tissue Engineering for Hair Follicle Regeneration-Full Text View-ClinicalTrials.gov. Available online: https://clinicaltrials.gov/ct2/show/NCT00506636 (accessed on 29 October 2020).

Publisher's Note: MDPI stays neutral with regard to jurisdictional claims in published maps and institutional affiliations.

(C) 2020 by the authors. Licensee MDPI, Basel, Switzerland. This article is an open access article distributed under the terms and conditions of the Creative Commons Attribution (CC BY) license (http://creativecommons.org/licenses/by/4.0/). 